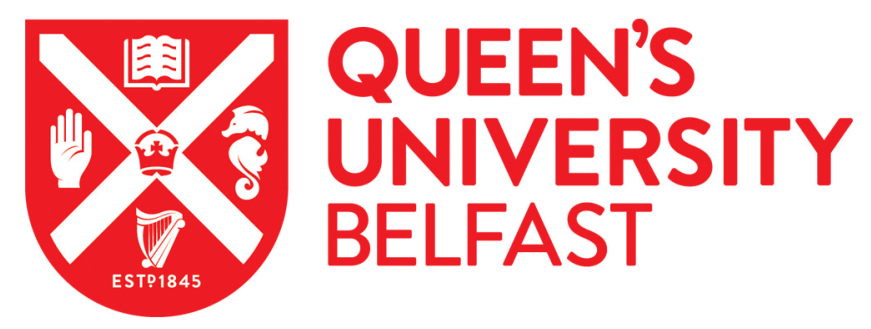

\title{
The inflammatory profile of exacerbations in patients with severe refractory eosinophilic asthma receiving mepolizumab (the MEX study): a prospective observational study
}

McDowell, P. J., Diver, S., Yang, F., Borg, C., Busby, J., Brown, V., Shrimanker, R., Cox, C., Brightling, C. E., Chaudhuri, R., Pavord, I. D., \& Heaney, L. G. (2021). The inflammatory profile of exacerbations in patients with severe refractory eosinophilic asthma receiving mepolizumab (the MEX study): a prospective observational study. The Lancet Respiratory Medicine, 9(10), 1174-1184. https://doi.org/10.1016/S2213-2600(21)00004-7

Published in:

The Lancet Respiratory Medicine

Document Version:

Peer reviewed version

Queen's University Belfast - Research Portal:

Link to publication record in Queen's University Belfast Research Portal

\author{
Publisher rights \\ Copyright 2020 Elsevier. \\ This manuscript is distributed under a Creative Commons Attribution-NonCommercial-NoDerivs License \\ (https://creativecommons.org/licenses/by-nc-nd/4.0/), which permits distribution and reproduction for non-commercial purposes, provided the \\ author and source are cited.
}

\section{General rights}

Copyright for the publications made accessible via the Queen's University Belfast Research Portal is retained by the author(s) and / or other copyright owners and it is a condition of accessing these publications that users recognise and abide by the legal requirements associated with these rights.

Take down policy

The Research Portal is Queen's institutional repository that provides access to Queen's research output. Every effort has been made to ensure that content in the Research Portal does not infringe any person's rights, or applicable UK laws. If you discover content in the Research Portal that you believe breaches copyright or violates any law, please contact openaccess@qub.ac.uk. 
A prospective observational study of the inflammatory profile of Mepolizumab EXacerbations in participants with severe refractory eosinophilic asthma (the MEX study).

P Jane McDowell ${ }^{1}$ MRCP(UK), Sarah Diver ${ }^{2}$ MRCP(UK), Freda Yang ${ }^{3}$ MRCP(UK), Catherine Borg ${ }^{4}$ MSc, John Busby ${ }^{5}$ PHD, Vanessa Brown ${ }^{1}$ PHD, Rahul Shrimanker ${ }^{4}$ MRCP(UK), Ciara Cox ${ }^{6}$ PHD , Professor Christopher E Brightling ${ }^{2}$ FMedSci, Professor Rekha Chaudhuri ${ }^{3}$ MD, Professor lan D Pavord ${ }^{4}$ FMedSci, Professor Liam G Heaney ${ }^{1}$ MD on behalf of the Medical Research Council: Refractory Asthma Stratification Programme (RASP-UK Consortium).

1-Centre for Experimental Medicine, School of Medicine, Dentistry, and Biological Sciences; Queen's University Belfast, Northern Ireland

2- Department of Respiratory Sciences, Leicester NIHR BRC, Institute for Lung Health, University of Leicester, Leicester, UK

3- Respiratory Medicine Section, Division of Immunology, Infection and Inflammation, University of Glasgow, Glasgow, UK

4-Oxford Respiratory NIHR BRC, Nuffield Department of Medicine, University of Oxford, UK 5-Centre for Public Health, School of Medicine, Dentistry, and Biological Sciences; Queen's University Belfast, Northern Ireland

6- Regional Virus Laboratory, Royal Victoria Hospital, Belfast Health and Social Care Trust

Corresponding author:

Liam G Heaney

Centre for Experimental medicine,

School of Medicine, Dentistry and Biomedical Sciences

Queen's University,

Belfast, UK.

Email: I.heaney@qub.ac.uk

Tel: +44 (0) 2890976376 


\section{Abstract}

Background: Clinical trials with anti-IL5 therapies show a $50 \%$ reduction in severe asthma exacerbations. Exacerbations on mepolizumab appear different from placebo, questioning their inflammatory phenotype and physiological characteristics.

Methods: This prospective observational study of 145 mepolizumab-treated participants was undertaken at four UK Severe Asthma Specialist clinics. Participants were aged between $18-80$ years old, with eosinophilic asthma (GINA steps 4 and 5) and suitable for access to mepolizumab therapy as per national UK guidelines. All participants received mepolizumab $100 \mathrm{mg}$ sc every four weeks, had a scheduled study visit when stable on mepolizumab ( $\geq 3$ months on treatment) and undertook daily peak flow and symptoms diaries throughout the course of the study. Participants attended their study centre for unscheduled exacerbation assessment when their symptoms worsened outside of their normal daily variation and prior to commencing treatment; exacerbation assessment included detailed medical history, examination, FeNO, spirometry, peripheral blood eosinophil count, CRP, and sputum induction, as well as blood and urine samples for biobanking. Where a participant was unable to attend their study centre for exacerbation or had initiated rescue treatment prior to study visit, clinical details of the missed exacerbation were collected by clinical staff. This study was exploratory with the end-point being 100 exacerbations assessed prior to treatment, and all measurements predetermined to precisely define exacerbation phenotype as per the study aims. Study analysis included description of the cohort and comparisons of subgroups within the cohort, including comparison of the characteristics of those who proceeded to exacerbate on mepolizumab and those who did not, comparison of peak flow and symptoms diaries for assessed and missed exacerbations and comparisons of exacerbation phenotypes defined by sputum cell count. Negative and positive predictive values were used to assess the utility of both FeNO and CRP in determining exacerbation phenotype on mepolizumab treatment. (Clinicaltrials.gov NCT03324230).

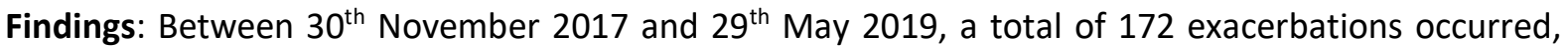
with 96 assessed prior to commencing treatment. Daily peak flow and symptoms diaries showed no difference in assessed and non-assessed exacerbations. At first assessed exacerbation per participant, $45 / 69$ (65\%) produced sputum of whom $47 \%$ were sputum eosinophil high $\geq 2 \%$ (SE ${ }^{H I G H}$ ) and $53 \%$ were sputum eosinophil low $<2 \%$ (SE $\left.{ }^{\text {LOW }}\right)$.

$\mathrm{SE}^{\mathrm{HIGH}}$ exacerbations were FeNO high (57ppb vs $24 \mathrm{ppb}$, median difference $33 ; 95 \% \mathrm{Cl} 8,87 ; \mathrm{p}<0.001$ ), with low FEV1\% predicted (55.6\% vs $71.5 \%$, mean difference $-15 \cdot 9 ; 95 \% \mathrm{Cl}-27 \cdot 0,-4 \cdot 8 ; p=0 \cdot 0075)$, obstructive spirometry ( $\mathrm{FEV}_{1} / \mathrm{FVC} 57 \cdot 5 \%$ vs $67 \cdot 8 \%$, mean difference $-10 \cdot 3 ; 95 \% \mathrm{Cl}-17 \cdot 0,-3 \cdot 6 ; \mathrm{p}=0 \cdot 0043$ ) 
and higher blood eosinophils (70 vs 30cells $/ \mu \mathrm{L}$, median difference $40 ; 95 \% \mathrm{Cl} 20,70 ; p<0.001$ ). In contrast, SE ${ }^{\text {LOW }}$ exacerbations were FeNO low, CRP high $(15 \mathrm{mg} / \mathrm{L}$ vs $2.3 \mathrm{mg} / \mathrm{L}$, median difference $12 \cdot 7$; $95 \% \mathrm{Cl} 3 \cdot 5,18 \cdot 5 ; p<0 \cdot 001)$, sputum neutrophil high (89.8\% vs $37 \cdot 1 \%$, median difference $52.7 ; 95 \% \mathrm{Cl}$ $34.5,59 \cdot 2 ; p<0.001$ ) and $50 \%$ received antibiotics ( $v 19 \%$ in $\mathrm{SE} \geq 2 \%, \mathrm{p} 0 \cdot 031$ ). FeNO ( $\leq 20$ or $\geq 50 \mathrm{ppb}$ ) was the most useful discriminator of inflammatory phenotype at exacerbation. The most common adverse event was hospital admission due to asthma exacerbation (17 of 34 events), none of the adverse events were study procedure related.

Interpretation: Exacerbations on mepolizumab are two distinct entities which can largely be differentiated using FeNO; non-eosinophilic events are driven by infection with a low FeNO and high CRP, while eosinophilic exacerbations are FeNO high. The results of the MEX study challenge the routine use of OCS for the treatment of all asthma exacerbation events on mepolizumab, as well as the switching of biological therapies for treatment failure without profiling the inflammatory phenotype of ongoing asthma exacerbations. The results highlight clinically available tools to enable profiling of these residual exacerbations in mepolizumab treated patients.

Funding: This study was funded in part by the Medical Research council UK (MR/M016579/1).

\section{Abstract word count: 253 words}

Manuscript word count: 3479 


\section{Research in context}

\section{Evidence before this study:}

The evidence available at the time of study conception was that through selective inhibition of eosinophilic inflammation, mepolizumab reduces exacerbations in those with severe, eosinophilic asthma, and decreases the need for maintenance systemic glucocorticoid therapy. However, the evidence also clearly showed a residual asthma exacerbation rate of approximately $50 \%$ in mepolizumab treated patients, for which oral corticosteroids were given.

A PubMed search of evidence available ('asthma', 'mepolizumab', 'exacerbation phenotype', end date 01/01/2017) gave 13 results, 12 of which were review articles outlining potential uses of mepolizumab and one cluster analysis of characteristics predicting response to mepolizumab, with no articles addressing the inflammatory phenotype of residual asthma exacerbations on mepolizumab. Post hoc analysis of mepolizumab phase III clinical trials by our study investigators showed physiological differences between mepolizumab and placebo treated patients, and suggested a differential response to treatment with oral corticosteroids, thus highlighting the need for a prospective study to understand the inflammatory phenotype of these residual asthma exacerbations, an as yet unmet research need.

\section{Added value of this study:}

Our study reveals that the exacerbations occurring in mepolizumab-treated patients are heterogeneous in nature with approximately half of the exacerbations due to ongoing $\mathrm{T} 2$, eosinophilic inflammation and with the other half being sputum eosinophil-low, sputum neutrophil-high, infectionassociated exacerbations with a significantly higher CRP. These events were essentially mutually exclusive and fractional inhaled nitric oxide (FeNO) was a useful discriminator of exacerbation inflammatory phenotype when high ( $\geq 50 \mathrm{ppb})$ or low $(\leq 20 \mathrm{ppb})$.

\section{Implications of all available evidence:}

Understanding the mechanisms behind residual exacerbations at the individual patient level in those treated with mepolizumab challenges the current clinical approach to management of exacerbations and longer-term treatment of those who continue to have recurrent exacerbations. Our study would suggest that treatment of eosinopenic, neutrophilic exacerbations with oral corticosteroids would be ineffective due to the absence of eosinophilic inflammation and that it could be potentially harmful to switch a patient with recurrent eosinopenic, neutrophilic exacerbations to a more eosinophildepleting biologic. Conversely, those with breakthrough eosinophilic exacerbations on mepolizumab are likely to respond to treatment with oral corticosteroids at exacerbation and to a more eosinophildepleting biologic. However, these findings need to be substantiated with further prospective studies 
to confirm that differentiating inflammatory phenotype at assessment of exacerbation will help guide better management. Further studies are also required to determine if the absence of airways eosinophils predisposes to airway infection. 


\section{Introduction}

The treatment of severe eosinophilic asthma has been transformed with the arrival of biological agents targeting the Type 2 cytokine pathway. ${ }^{1}$ One of these is mepolizumab, a humanised monoclonal antibody against the eosinophil activating cytokine interleukin 5 (IL5), which has consistently shown a $50 \%$ reduction in exacerbation rate when compared to placebo in patients with severe eosinophilic asthma. ${ }^{2-4}$

There has been significant interest in the inflammatory phenotype and mechanism of the residual exacerbations in these patients. To date, analyses have compared exacerbations on mepolizumab to those on placebo in randomised controlled trials. Shrimanker et al showed that at the time of exacerbation, mepolizumab-treated participants had a lower sputum eosinophil count with fewer symptoms, ${ }^{5}$ and a subsequent post-hoc analysis of three phase III clinical trials ${ }^{2,4,6}$ suggested less impairment of peak expiratory flow (PEF) and fewer symptoms compared to placebo treated participants. ${ }^{7}$ These analyses suggested that exacerbations were less severe and potentially due to different mechanisms in mepolizumab-treated participants. Further study of inflammatory profile and mechanisms of exacerbation in mepolizumab-treated participants is required.

The aim of this study was to explore the inflammatory phenotype and physiological characteristics of exacerbation events from a cohort of severe, eosinophilic asthmatics treated with mepolizumab.

\section{Methods}

Participants were aged $18-80$ years old with a diagnosis of severe asthma (GINA steps 4 and 5$)^{8}$ and eligible for treatment with mepolizumab in line with UK Clinical Guidelines with an oral corticosteroid (OCS) requirement of either maintenance OCS or 4 exacerbations in the preceding year. ${ }^{9,10}$ Full inclusion and exclusion criteria are in the Online Supplement (online supplement page 1); subjects had to have no asthma exacerbations requiring oral corticosteroids (OCS) in the 4 weeks prior to the first study visit. The Office for Research Ethics Northern Ireland granted ethical approval and local National Health Service Research and Development approval was obtained for individual sites. All participants provided written informed consent prior to study entry. The study was registered on clinicaltrials.gov (NCT03324230) and the study protocol can be found at https://rasp.org.uk/MEX/Exacerbation mepolizumab prtcl V1.0 18AUG17.pdf

\section{Study design}


MEX was a multicentre, prospective observational study performed in four UK specialist severe asthma centres and all outcome measures were exploratory. Mepolizumab 100mg was administrated by subcutaneous injection every 4 weeks. All patients had a study visit after at least 3 months mepolizumab to define clinical and inflammatory status when clinically stable on treatment. Demographic and clinical details were obtained for all subjects prior to initiation of mepolizumab and in those patients who were initiating mepolizumab at study entry; an additional study visit was performed prior to initiation of drug, Figure E1 (online supplement, page 2). An exacerbation was defined as severe asthma symptoms worsening outside of a patient's normal daily variation and occurring any time after the initial dose of mepolizumab, at which point participants attended their clinical site for assessment prior to commencing rescue treatment. All study visits included detailed medical history, examination, fractional exhaled nitric oxide (FeNO), spirometry, peripheral blood eosinophil count (PBE), C-reactive protein (CRP), and sputum induction with hypertonic saline (up to 5\%). Participants completed asthma control and quality of life questionnaires (asthma control questionnaire 5 (ACQ-5), mini-asthma quality of life questionnaire (mini-AQLQ), and St George's respiratory questionnaire (SGRQ), (details in online supplement page 3). ${ }^{11-13}$ All participants were provided with an electronic PEF recorder and daily symptoms diary for the duration of the study.

Clinical assessment and management of each exacerbation was in line with standard clinical guidelines ${ }^{14}$ and was blind to the assessment of sputum inflammatory characteristics. All unscheduled visits were followed up with a telephone call 2-3 days post-visit. For exacerbation events where the patient was unable to attend for clinical assessment or had initiated rescue treatment prior to study visit (missed exacerbations), patients were advised to manage these according to their selfmanagement plan and clinical staff collected clinical details of the exacerbation. We assumed 0.7 exacerbations per patient per year on mepolizumab (ca 160 events in an 18-month period) and a minimum rate of attendance of $65 \%$. The study endpoint was 100 clinical assessments at exacerbation completed across all sites for participants on mepolizumab prior to initiation of rescue treatment.

\section{Procedures}

Twice daily PEF were recorded using Vitalograph Asma $1^{\circledR}$ ePEF meter and daily recording of severity of symptoms, nocturnal wakening and daily reliever medication use via a standardized asthma symptoms diary. FeNO measurement was undertaken using NIOX Vero ${ }^{\circledR}$ and spirometry conducted according to the American Thoracic Society/European Respiratory Society consensus statement ${ }^{15}$ with $\mathrm{FEV}_{1}$ and FVC percent-predicted values calculated using global lung function 2012 equations. ${ }^{16}$ Sputum was induced and processed in line with the RASP-UK standard operating procedure. Sputum nucleic acid extracts underwent polymerase chain reaction (PCR) using LightCycler $^{\circledast} 480$ II 
instrumentation (Roche Molecular Diagnostics) to indicate presence of a respiratory virus including Influenza A/B, Respiratory syncytial virus A/B, Rhinovirus, Metapneumovirus, Adenoviurs, Parainfluenza 1-4, and Coronavirus. DNA was extracted from sputum plugs and bacterial loads measured by quantitative PCR (qPCR), using ThermoFisher Quantstudio 5, based on abundance of $16 \mathrm{~S}$ ribosomal subunit encoding genes and pathogen specific genes including Moraxella catarrhalis, Haemophilus influenzae, and Streptococcus pneumonia as previously described. ${ }^{17}$ We used a specific bacteria threshold of $\geq 10^{\wedge} 6$ genome copies $/ \mathrm{ml}$ on sputum $\mathrm{qPCR}$ as significant because this threshold of detection had a $98 \%$ concordance with bacteria detection on routine culture and was associated with an increased percentage sputum neutrophils in COPD exacerbations. ${ }^{18}$

\section{Statistical analysis}

Descriptive statistics are presented as means (SD), medians [IQR] or counts (\%) as appropriate. For normally-distributed variables, we compared groups using the mean difference and independent sample or paired t-test. For non-normally distributed variables, we compared groups using the median difference (with bootstrapped $95 \% \mathrm{Cls}$ ) and Mann-Whitney $\mathrm{U}$ or Wilcoxon signed rank tests. Differences for categorical variables were summarised using odd ratios ( $95 \% \mathrm{Cls})$, with p-values derived from chi-squared tests. Spearman's correlation analysis were utilised to describe the relationship between variables. To examine if study assessed exacerbations were different physiological entities from those where the study participant did not attend the clinic, daily PEF and symptoms diaries were compared before and after the index date for the exacerbation. Mean change in PEF and symptom diary scores from 14 days prior to and following the exacerbation nadir were plotted for patient subgroups and compared. To ensure there was no bias introduced from repeated exacerbations in an individual patient, each participant's first exacerbation was used when comparing to the baseline assessment. Inflammatory phenotype at exacerbation was assessed using sputum eosinophils; the first exacerbation with sputum per participant was divided into sputum eosinophil low (SE ${ }^{\text {LOW }}$, sputum eosinophil count $<2 \%$ at exacerbation) and sputum eosinophil high (SE ${ }^{\text {HIGH }}$, sputum eosinophil count $\geq 2 \%$ at exacerbation). A cut-point of $2 \%$ sputum eosinophils was used to signify the presence of type 2 inflammation in line with GINA guidelines. ${ }^{19}$ As data was collected prospectively during exacerbations, missing data was rare. Therefore, we conducted all analyses under a completecase framework. Analyses were conducted using STATA 16 (StataCorp, Texas, USA).

\section{Role of the funding}


The funder of the study had no role in study design, data collection, data analysis, data interpretation, or writing of the report. All authors had access to all of the data in the study and had final responsibility for the decision to submit for publication.

\section{Results}

Between the $30^{\text {th }}$ of November 2017 and $29^{\text {th }}$ of May 2019, 145 participants were recruited, 93 preestablished on mepolizumab (median time on mepolizumab 0.46 years $[0.31,0.83]$ ) and 52 new to mepolizumab. Five participants pre-established on mepolizumab had no engagement with any study procedures following their initial study visit and were excluded from further analysis. Demographics, including comorbidities, prior to initiation of mepolizumab are in table E1 (online supplement, page 4) and characteristics when clinically stable on mepolizumab ( $\geq 3$ months treatment) are in Table 1. When clinically stable on mepolizumab, $75 \%$ (102/140) of participants were receiving maintenance prednisolone (median dose $10[5,10] \mathrm{mg} /$ day), participants continued to have considerable symptoms and impaired quality of life (ACQ-5 2.0 (1.0,3.0), mini-AQLQ $4 \cdot 6(3 \cdot 3,6 \cdot 4)$, SGRQ $46 \cdot 1(21 \cdot 5,63 \cdot 3)$ impaired lung function (FEV $171 \cdot 8 \%(20 \cdot 9)$, and elevated FeNO $(32 \cdot 5 \mathrm{ppb}[19,66])$. Although PBE were suppressed on mepolizumab compared to the pre-mepolizumab state, $23 \%$ (31/135) of participants continued to have PBE of $\geq 100$ cells/ $\mu \mathrm{L}$ detected and $41 \%$ (31/75) of sputum producers a sputum eosinophilia of $\geq 2 \%$ (Table 1, Figure E2).

Thirty-four serious adverse events were reported, none were directly related to study procedures and half were hospitalisations due to asthma exacerbations, (Table E2, online supplement, page 5). There were 29 study withdrawals (details in Figure 1).

\section{Exacerbations}

There were a total of 172 exacerbations in 87/140 (62\%) participants; 96 exacerbations were assessed prior to initiation of antibiotic or OCS treatment and of the remaining 76 missed exacerbations, 65 were unable to attend the clinic and 11 were assessed at the clinic but participants had already initiated rescue treatment (OCS $n=2$, antibiotics $n=8$ or both $n=1$, Figure 1 ). The remaining $53 / 140$ (38\%) participants were exacerbation-free.

Comparing those who did and did not exacerbate during the study (Table E3, online supplement page 7), subjects who exacerbated had a higher exacerbation rate and more emergency department (ED) visits in the year prior to commencing mepolizumab, but no other defining clinical characteristics. On 
mepolizumab there was no difference in $\mathrm{PBE}$, sputum or FeNO, although those who exacerbated experienced a higher symptom burden.

\section{Missed exacerbations}

The symptoms experienced during missed exacerbations are shown in Table E4 (online supplement, page 8). Most participants saw their general practitioner $(46 \%, 35 / 76)$ or self-treated as per their personalised asthma action plan (42\%, 32/76) with 91\% (69/76) commencing high dose OCS and 57\% (43/76) antibiotics. There were 12 hospital admissions; four participants commenced rescue treatment but contacted their study teams and were subsequently admitted by the study clinician, the remaining eight were admitted directly through acute medical services. Comparing the PEF of assessed and missed exacerbations, the mean (SD) change in PEF at nadir in the assessed group was $40.5 \mathrm{~L} / \mathrm{min}(76.3)$ and $-37.0 \mathrm{~L} / \mathrm{min}(93.0)$ in the missed group, $\mathrm{p}=0.84$ and there was no difference in reported symptom burden (Figure 2).

Assessed exacerbations prior to rescue treatment

Details of all 96 exacerbations assessed prior to rescue treatment are illustrated in Table E5 (online supplement, page 9); these occurred in 69 subjects with 21 having a second exacerbation and 6 a third. Mean ACQ-5 was $3 \cdot 6(2 \cdot 6,4 \cdot 1)$ with 58 of 91 exacerbations with paired ACQ-5 measurements having an increase of $\geq 0.5$ from baseline. Median FeNO was 47ppb [22,81] with $47.3 \%$ (43/91) of exacerbations having a FeNO of $\geq 50 \mathrm{ppb}$ and $23 \%$ (21/93) of participants a PBE count of $\geq 100$ cells/ $\mu \mathrm{L}$. Median sputum eosinophil count was $1 \cdot 3 \%[0 \cdot 3,10 \cdot 4]$ with $48 \%(28 / 59)$ having an eosinophil count of $\geq 2 \%$. Median sputum neutrophil count was $59.5 \%$ [33.4,91.9] with $48 \%(28 / 59)$ of exacerbation sputa having a neutrophil count of $\geq 65 \%$; there was minimal overlap between the sputum eosinophil high exacerbations and sputum neutrophil high exacerbations (3/59 exacerbations). Treatment at clinic resulted in $64 \%(61 / 96)$ of participants receiving OCS and $27 \%(26 / 96)$ antibiotics; at follow-up telephone call after the unscheduled visit, 13 participants had gone on to commence OCS and three had started antibiotics (Table E5, online supplement page 9). Table E6 illustrates the change in participant characteristics from stable on mepolizumab to first exacerbation per participant $(n=69)$ (online supplement, page 10).

To examine the inflammatory phenotype of exacerbation events, the first exacerbation per participant with sputum was divided into SE ${ }^{\mathrm{LOW}}$ and $\mathrm{SE}^{\mathrm{HIGH}}$. On commencing mepolizumab, there was no difference in the clinical characteristics of the $\mathrm{SE}^{\mathrm{HIGH}}$ and $\mathrm{SE}^{\mathrm{LOW}}$ exacerbation subgroups (Table E7, online supplement page 11). When stable on mepolizumab, the $\mathrm{SE}^{\mathrm{HIGH}}$ exacerbation group had higher sputum 
eosinophils, higher FENO but no difference in PBE, CRP, or maintenance prednisolone (Table E8, online supplement page 12). At exacerbation, there was no difference in maintenance prednisolone exposure (Table 2). The $\mathrm{SE}^{\mathrm{HIGH}}$ group had a higher FeNO (57ppb vs $24 \mathrm{ppb}$, median difference 33; 95\% $\mathrm{Cl} 8,87 ; \mathrm{p}<0 \cdot 001)$, lower $\mathrm{FEV}_{1}(55 \cdot 6 \%$ vs $71 \cdot 5 \%$, mean difference $-15 \cdot 88 ; 95 \% \mathrm{Cl}-27 \cdot 0,-4 \cdot 8 ; \mathrm{p}=0 \cdot 0075)$ and more obstructive spirometry (FEV 1 /FVC $57 \cdot 5 \%$ vs $67 \cdot 8 \%$, mean difference $-10 \cdot 3 ; 95 \% \mathrm{Cl}-17 \cdot 0$,3.6; $p=0.0043)$. Pre-defined clinical diagnoses assigned at time of assessment were different between the two inflammatory phenotypes $(p=0 \cdot 04)$, with the $S E^{\text {LOW }}$ group more likely to be diagnosed with an infectious trigger ( $88 \% \vee 40 \%$ ) and more likely to receive antibiotics as part of their treatment plan ( $50 \%$ vs $19 \%, p=0 \cdot 031$ ). There were three hospital admissions in the $\mathrm{SE}^{\mathrm{LOW}}$ group ( 1 at the time of assessment and 2 within 3 days of assessment) and none in the $\mathrm{SE}^{\mathrm{HIGH}}$ group. At exacerbation, the $\mathrm{SE}^{\mathrm{LOW}}$ subgroup had lower PBE (30cells/ $\mu \mathrm{g}$ vs 70 cells/ $\mu \mathrm{g}$, median difference $-40 ; 95 \% \mathrm{Cl}-70,-20$; $\mathrm{p}<0.001)$, higher CRP (15mg/L vs $2.3 \mathrm{mg} / \mathrm{L}$, median difference $12.7 ; 95 \% \mathrm{Cl} 3.5,18.5 ; \mathrm{p}<0.001)$, and higher sputum neutrophils (89.8\% vs $37 \cdot 1 \%$, median difference $52 \cdot 7 ; 95 \% \mathrm{Cl} 34 \cdot 5,59 \cdot 2 ; p<0 \cdot 001$ ). Lung function was significantly lower in the $\mathrm{SE}^{\mathrm{HIGH}}$ group at exacerbation, representing an additive effect of an $8.9 \%$ lower $\mathrm{FEV}_{1}$ in the $\mathrm{SE}^{\mathrm{HIGH}}$ when stable on mepolizumab alongside a $4.5 \%$ greater decrement at exacerbation (Table E8 and Table E9). FeNO did not change at exacerbation in either group, Table E9 (online supplement, page 13).

FeNO correlated significantly with sputum eosinophils at the time of exacerbation (rho 0.56, p<0.001). In total, 57 exacerbations had both sputum differential cell counts and FeNO (Figure 3); 25\% (14/57) had a low FeNO ( $\leq 20 \mathrm{ppb})$ at exacerbation of which none had a sputum eosinophil count of $\geq 2 \%$ i.e negative predictive value (NPV) of FeNO $\leq 20 \mathrm{ppb}$ for eosinophilic sputum at exacerbation was $100 \%$ $(95 \% \mathrm{Cl} 80,100)$. Twenty of 26 exacerbations with a high FeNO ( $\geq 50 \mathrm{ppb})$ at exacerbation had a sputum eosinophil count of $\geq 2 \%$ (median sputum eosinophil count $7 \cdot 2 \%[2 \cdot 6,30 \cdot 5]$ ) i.e. positive predictive value (PPV) of FeNO $\geq 50 \mathrm{ppb}$ for airway eosinophilia was $77 \%(95 \% \mathrm{Cl} 60,90)$. The $30 \%(17 / 57)$ of exacerbations with a FeNO between 21-49ppb were more heterogeneous with 53\% (9/17) SE ${ }^{\mathrm{LOW}}$ and $47 \%(8 / 17) \mathrm{SE}^{\mathrm{HIGH}}$.

For all 91 exacerbations with FeNO measurements, there were 22 (24\%) FeNO low ( $\leq 20 \mathrm{ppb}), 25$ (28\%) FeNO intermediate (21-49ppb), and $44(48 \%)$ FeNO high ( $\geq 50 \mathrm{ppb})$. Similar to sputum eosinophil analyses, the FeNO subgroups differentiated at exacerbation on PBE $(0 \cdot 30[20,60], 30[20,60]$, $70[40,120$ cells $/ \mu \mathrm{L}], p=0 \cdot 0020), \operatorname{CRP}(11 \cdot 5[4 \cdot 9,23 \cdot 0], 5 \cdot 7[2 \cdot 3,13 \cdot 0], 3 \cdot 6[1 \cdot 4,5 \cdot 7] \mathrm{mg} / \mathrm{L}, \mathrm{p}=0.009)$, sputum eosinophils $(n=57) 0 \cdot 3[0 \cdot 2,0 \cdot 5], 1 \cdot 0[0 \cdot 6,4 \cdot 5], 7 \cdot 2[2 \cdot 5,33 \cdot 0] \%, p<0 \cdot 001)$, and respiratory viral PCR positivity $(41 \cdot 7 \%, 60 \%, 16 \cdot 7 \% \mathrm{p}=0 \cdot 020)$. 
CRP had a significant inverse correlation with sputum eosinophils at the time of exacerbation (rho= $0.57, p<0.001)$. Of the 57 exacerbations with a paired sputum cell differential and CRP at exacerbation, $31 / 57$ (54.5\%) had a CRP of $\leq 5 \mathrm{mg} / \mathrm{L}$ and of these, $22 / 31$ had a sputum eosinophil count of $\geq 2 \%$, therefore CRP $\leq 5 \mathrm{mg} / \mathrm{L}$ has a $71.0 \%$ PPV $(95 \% \mathrm{Cl} 52.0,85.8)$ for predicting a sputum eosinophil count of $\geq 2 \%$. The remaining $26 / 57$ exacerbations had a CRP $>5 \mathrm{mg} / \mathrm{L}$, of these $21 / 26$ had a sputum eosinophil count of $<2 \%$, therefore CRP $>5 \mathrm{mg} / \mathrm{L}$ has an $80.8 \%(95 \% \mathrm{Cl} 60.6,93.4)$ NPV for excluding a sputum eosinophil count $\geq 2 \%$ at exacerbation. CRP was not of value in providing further differentiation of exacerbation phenotype in the intermediate FeNO group (FeNO 21-49ppb) (data not shown).

To explore the relationship between sputum phenotype when stable and at exacerbation, paired sputum ( $n=24$ subjects) were examined; 38\% (9/24) were $\mathrm{SE}^{\mathrm{HIH}}$ both when stable on mepolizumab and at exacerbation, $33 \%(8 / 24)$ were $\mathrm{SE}^{\mathrm{LOW}}$ when stable on mepolizumab and at exacerbation (Figure E3, online supplement page 14 ), in total $71 \%$ had a preserved inflammatory phenotype. Similarly for those with paired FeNO measurements when stable on mepolizumab and exacerbation, 68\% (13/19) had FeNO $\leq 20 \mathrm{ppb}$ when stable and at exacerbation and 60\% (26/43) had FeNO $250 \mathrm{ppb}$ when stable and at exacerbation. Of the 75 participants with a sputum sample when clinically stable on mepolizumab, $50 \%(22 / 44)$ of the $\mathrm{SE}^{\mathrm{LOW}}$ and $53 \%(18 / 31)$ of the $\mathrm{SE}^{\mathrm{HIGH}}$ went on to have an exacerbation during the study period $(\operatorname{Pr}=0 \cdot 46)$. There was no difference in annualised rate of exacerbations between the $\mathrm{SE}^{\mathrm{LOW}}$ and $\mathrm{SE}^{\mathrm{HIGH}}$ groups (1.23 vs $\left.1 \cdot 23\right)$.

When clinically stable on mepolizumab, $57 \%$ (39/69) of patients had bacteria detected by PCR, $36 \%$ $(25 / 69)$ had bacteria detected over the $10^{\wedge} 6$ genome copies/ml threshold and $12 \%(8 / 69)$ had a virus detected on PCR (Table 1). Presence of bacteria or virus on sputum PCR while clinically stable on mepolizumab was not associated with an increase in sputum neutrophils (Table E10, online supplement page 15$)$. When clinically stable on mepolizumab, the study exacerbators were no more likely to have a virus or specific bacteria above the level of detection or above the threshold of $10^{\wedge} 6$ genome copies/ml, than the non-exacerbators (Table E3, online supplement page 7).

At first exacerbation with sputum, $67 \%$ (22/33) of patients had bacteria detected by qPCR, there was no significant difference in sputum neutrophil count for those that had bacteria detected at any threshold on qPCR compared to those that did not (Table E10, online supplement page 15). Thirtynine percent $(13 / 33)$ had bacteria $\geq 10^{\wedge} 6$ genome copies/ml detected on qPCR with an associated increase in sputum neutrophil count (sputum neutrophils 95\% [62.3,97.7] vs 64\% [36.8,88.4], $p=0 \cdot 025)$. The $36 \%(12 / 33)$ of exacerbations with a virus detected on PCR at exacerbation did not have an associated increase in sputum neutrophils (Table E10). 
Applying the $\mathrm{SE}^{\mathrm{LOW}}$ and $\mathrm{SE}^{\mathrm{HIGH}}$ phenotypes to the first exacerbation with sputum per participant, $\mathrm{SE}^{\mathrm{LOW}}$ exacerbations had a two fold increase in the number of viruses detected on PCR ( $45 \%$ vs $23 \%, p=0 \cdot 20$ ), a two fold increase in those with a specific bacteria $\geq 10^{\wedge} 6$ genome copies $/ \mathrm{ml}(50 \%$ vs $23 \%, p=0 \cdot 12$ ), and were significantly more likely to have either a virus or specific bacteria $\geq 10^{\wedge} 6$ genome copies $/ \mathrm{ml}$ in sputum at exacerbation ( $\mathrm{SE}^{\mathrm{LOW}} 75 \%$ vs $\mathrm{SE}^{\mathrm{HIGH}} 38 \%$, mean difference $0 \cdot 21 ; 95 \% \mathrm{Cl} 0 \cdot 04,1 \cdot 2 ; \mathrm{p}=0.036$, Table 2).

\section{Discussion}

Prospective evaluation of asthma exacerbations on mepolizumab indicates that these are heterogeneous in nature with approximately half driven by eosinophilic inflammation and half being non-eosinophilic events with an increased propensity for pathogen-driven exacerbations. These appear to be broadly mutually exclusive events and FeNO at exacerbation is useful in discriminating between eosinophilic and non-eosinophilic exacerbations.

When stable on mepolizumab, this cohort had continuing asthma symptoms and evidence of ongoing T2 activity. Those who exacerbated on mepolizumab had a higher pre-mepolizumab exacerbation rate and ED attendance, and higher symptom scores. There was no significant difference in clinical or sputum characteristics, in particular no difference in sputum eosinophil count and FeNO, in those who exacerbated and those who did not exacerbate during the study. For all assessed exacerbations, there was no evidence of increased exacerbation towards the end of the 4-week mepolizumab treatment period (Table E5, online supplement page 9), and no difference in time since last mepolizumab administration to exacerbation between $\mathrm{SE}^{\mathrm{LOW}}$ and $\mathrm{SE}^{\mathrm{HIGH}}$ subgroups (Table 2), supporting the findings of a recent post-hoc analysis of the DREAM study. ${ }^{20}$

We anticipated loss of $35 \%$ of exacerbation events due to inability to attend ( $38 \%$ during study). Symptom burden and PEF change were similar for assessed and missed exacerbations, suggesting that the assessed exacerbation events were representative of all exacerbations experienced by study participants. For assessed exacerbations, symptom worsening and lung function fall resulted in the majority (64\%) receiving rescue OCS at exacerbation assessment; interestingly, 13 of the 35 patients who did not receive OCS treatment at study assessment went on to initiate OCS in the days following this suggesting slow recovery or worsening; in many of these, there was no evidence of eosinophilic inflammation at assessment and the benefit of the OCS is questionable.

There was little difference in the clinical characteristics of the $\mathrm{SE}^{\mathrm{LOW}}$ and $\mathrm{SE}^{\mathrm{HIGH}}$ exacerbator groups on initiation of mepolizumab therapy, however, once established on mepolizumab differences become 
apparent even when clinically stable. The $\mathrm{SE}^{\mathrm{HIGH}}$ group had evidence of ongoing T2-inflammation, higher FeNO and higher percentage sputum eosinophils, despite no difference in OCS exposure or PBE suggesting a difference in airways biology.

At exacerbation, the $S E^{\mathrm{LOW}}$ subgroup do have a large symptom increase, fall in lung function, and all hospital admissions occurred in this group (confirming these are clinically significant events). The SE ${ }^{\text {LOW }}$ events had neutrophilic sputum, higher CRP, were more likely to be clinically diagnosed with a pathogen-driven event, and to have a virus or bacteria $\left(\geq 10^{\wedge} 6\right.$ copies $/ \mathrm{ml}$ ) on PCR at exacerbation. In contrast, $\mathrm{SE}^{\mathrm{HIGH}}$ exacerbations had higher PBE, lower $\mathrm{FEV}_{1}$, more obstructed spirometry, and higher FeNO in keeping with T2 cytokine activity and eosinophilic airways inflammation. Importantly, these seem to be dichotomous mutually exclusive events with few patients having evidence of overlapping neutrophilic/eosinophilic sputum, in keeping with previous findings in COPD exacerbations. ${ }^{17,21}$ It is notable that FeNO does not change at acute exacerbation from the stable state, suggesting that substantial upregulation of IL4/IL13 pathways is not an obvious driving factor for eosinophilic exacerbation events, although these inflammatory pathways are still active (accepting FeNO as a surrogate biomarker) and also suggests that non-adherence to background ICS is not a likely driver.. ${ }^{22}$ It has been suggested that in situ eosinopoiesis orchestrated by ILC2 cells may occur ${ }^{23}$ or other autoimmune mechanisms. ${ }^{24}$ Understanding the precise mechanism of persistent eosinophilic recruitment despite substantial depletion of the circulating pool and how this translates into a clinical deterioration is an important area for future research.

The fact that non-eosinophilic events are more likely to be associated with pathogen-driven events, alongside the inverse correlation between CRP and sputum eosinophil count at exacerbation, raises the question as to whether suppression of eosinophils in the airway predisposes to airway infection. The role of eosinophils against helminths is well known, but eosinophils may also play a role against viral, bacterial, or fungal organisms and have a variety of pathogen killing mechanisms. ${ }^{25,26}$ Previous studies have suggested the absence of eosinophils in humans does not appear to be associated with significant adverse events, ${ }^{27}$ however, this topical question is being re-debated in light of the association of eosinopenia with severe COVID-19 infection, ${ }^{28,29}$ and in particular the risks of medication-induced eosinopenia during this global pandemic. ${ }^{30}$ Furthermore, exacerbations in benralizumab (an eosinophil depleting antibody) treated patients have been described as noneosinophilic and associated with a significant increase in respiratory infections. ${ }^{31}$ This is currently being further evaluated in the UK Refractory Asthma Stratification Programme. ${ }^{32}$ The benefit of prophylactic macrolides in reducing exacerbation rate, and importantly the rate of respiratory tract infections, in severe asthmatics is presented in the AMAZES trial. ${ }^{39}$ Further prospective research into the utility of prophylactic antibiotics as add-on therapy to mepolizumab and other anti-T2 biologics 
will be important. Assessment of the presence of airways dilatation/bronchiectasis as part of baseline characteristics will also be an important part of further studies investigating neutrophilic exacerbations in eosinophil-depleting biologics.

PBE count is an established biomarker of T2 biology, exacerbation risk and steroid responsiveness in asthmatic patients, ${ }^{33-38}$ but the addition of mepolizumab and other anti-IL5 biologics makes this biomarker less useful as a prognostic agent. Sputum differential cell count is not straightforward to measure, has not translated into routine clinical care and is likely to be challenging for routine assessment during an exacerbation. FeNO is an easy to perform, widely available near-patient test, and has useful discriminatory value between $\mathrm{SE}^{\mathrm{LOW}}$ and $\mathrm{SE}^{\mathrm{HIGH}}$ events in mepolizumab treated patients at exacerbation. We would suggest that FeNO is measured at exacerbation and when low (FeNO $\leq 20 \mathrm{ppb}$ ), careful consideration be given to use of OCS and antibiotics be considered, and when high (FeNO $\geq 50 \mathrm{ppb}$ ), OCS are likely to be indicated. Middle-range FeNO values (21-49ppb) are not discriminatory and further consideration of the mechanism of exacerbation and treatment on clinical grounds need to be considered. We acknowledge that this hypothesis, particularly the role of antibiotics in mepolizumab treated participants, needs formal evaluation in a placebo-controlled trial. CRP also has clinical utility in the assessment of exacerbations, particularly where FeNO measurement is not available. The significant inverse correlation between CRP and sputum eosinophils at the time of exacerbation is supportive of sputum-eosinophil low exacerbations being infective in nature. Although a CRP cut point of $5 \mathrm{mg} / \mathrm{L}$ was useful in discriminating inflammatory phenotype at exacerbation, CRP did not perform as well as FeNO in predictive value of inflammatory phenotype at exacerbation. In addition, CRP did not provide further differentiation of exacerbation phenotype in those with an intermediate FeNO (21-49ppb).The exacerbation rate in $\mathrm{SE}^{\mathrm{LOW}}$ and $\mathrm{SE}^{\mathrm{HIGH}}$ subjects when stable on mepolizumab is no different. Inflammatory phenotype assessed using sputum or FeNO is relatively preserved between the stable and exacerbation state, although this is not entirely reliable with approximately a third of subjects changing inflammatory phenotype between baseline and exacerbation. In addition, we would conclude that being on maintenance prednisolone whilst on mepolizumab therapy does not predict clinical response, as there was no difference in maintenance prednisolone dose in those who went on to exacerbate during this study and those who did not. Further, maintenance prednisolone therapy does not exclude breakthrough eosinophilic exacerbations while on mepolizumab or relate to the inflammatory phenotype at exacerbation.

In summary, exacerbation events in mepolizumab-treated severe asthmatics with severe refractory eosinophilic asthma are heterogeneous, but have two mutually exclusive phenotypes; noneosinophilic pathogen-driven and sputum eosinophil high exacerbations secondary to T2-eosinophilic inflammation. Further studies are needed to evaluate whether differentiating inflammatory 
phenotype at assessment of exacerbation will help guide management of increased symptoms triggered by either infectious agents with antibiotics or concomitant macrolide therapy in recurrent exacerbations versus OCS or switching to a more eosinophil-depleting biologic for those with breakthrough T2-driven exacerbations. Studies are also required to assess whether more eosinophildepleting biological agents, such as anti-IL5-R and anti-TSLP, predispose to infection-related neutrophilic events. 


\section{Authorship}

$\mathrm{LH}, \mathrm{IP}, \mathrm{RC}$ and $\mathrm{CB}$ led the study design process. All authors contributed to the design review. PJM, SD, $J Y, C B$ and RS were responsible for data acquisition. LH, PJM and JB were responsible for data analysis. All authors contributed to the interpretation of the data, to the reviews and the edit drafts of the manuscript, approved the final draft of the manuscript for submission and agree to be accountable for all aspects of the work.

\section{Acknowledgements}

We acknowledge the work of the laboratory staff and clinical staff across the four sites who assisted with this work: Christopher Wise, Christine McAnally, Stephen Drain, William Monterio, Hannah Arnold, Claudia Micieli, Vijay Mistry, Marc Jones, Hattie Ellis, Samantha Thulborn and Linda Cheyne for their laboratory work. Esther Ramsey, Sarah Howes, Michelle Bourne, Tracy Thorton, Sarah Edwards, Helen Evans, Steven Smith, Tracyanne Grandison and Clare Conolly for their clinical contributions. This study was funded jointly by the Medical Research Council (MRC) UK (MR/M016579/1) and industrial partners within the MRC Refractory Asthma Stratification Program consortium. None of the Industry partners had a role in the design or delivery of the study or submission, drafting or approval of final manuscript. All listed authors had full access to all the data in the study and approved the decision to submit for publication.

\section{Declaration of interests:}

$\mathrm{SD}, \mathrm{CB}, \mathrm{JB}, \mathrm{VB}, \mathrm{RS}$ and $\mathrm{CC}$ have no financial or personal relationships to declare. PJM reports other from Glaxo Smith Kline, outside the submitted work. FY reports personal fees and non-financial support from AstraZeneca, non-financial support from GlaxoSmithKline, outside the submitted work. CEB reports grants and personal fees from GSK, grants and personal fees from AZ, grants and personal fees from Sanofi, grants and personal fees from Novartis, grants and personal fees from Chiesi, grants and personal fees from Genentech, grants and personal fees from Gossamer, grants and personal fees from Mologic, grants and personal fees from 4DPharma for services outside the submitted work. RC reports grants, personal fees and non-financial support from AstraZeneca, personal fees from GSK, personal fees and non-financial support from Teva, personal fees from Novartis, personal fees and non-financial support from Chiesi, non-financial support from Napp Pharmaceuticals, outside the submitted work. IDP reports other from Sanofi, other from Regeneron Pharmaceuticals, Inc., non-financial support from Excerpta Medica, during the conduct of the study; other from Aerocrine $A B$, other from Almirall, other from AstraZeneca, other from Boehringer 
Ingelheim, grants and other from Chiesi, other from GSK, other from Novartis, other from Regeneron Pharmaceuticals, Inc, other from Sanofi, other from Teva , other from Circassia, other from Dey Pharma, other from Genentech, other from Knopp Biosciences, other from Merck, other from MSD, other from Napp Pharmaceuticals, other from RespiVert, other from Schering-Plough, outside the submitted work. LGH reports non-financial support from GlaxoSmithKline during the conduct of the study; grants from Amgen, AstraZeneca, Medimmune, Janssen, Novartis, Roche / Genentech, GlaxoSmithKline plc., Boehringer Ingelheim, Aerocrine and Vitalograph, other from Novartis, Hoffman la Roche/Genentech Inc, Evelo Biosciences, Sanofi, Glaxo Smith Kline, Astra Zeneca, Teva, Theravance, Circassia, other from AstraZeneca, Boehringer Ingelheim, Chiesi, GSK and Napp Pharmaceutical, other from Medimmune, Novartis UK, Roche / Genentech, and GlaxoSmithKline plc., from Astra Zeneca, GlaxoSmithKline, Schering Plough, Synairgen, Novartis, and Roche / Genentech), outside the submitted work.

\section{Data sharing:}

Following publication of the primary and secondary analyses, we plan to evaluate how best to share individual de-identified patient data, including data dictionary, in keeping with the data-sharing practices of the RASP-UK consortium. This will allow for maximum utilisation of the data to improve patient care and advance medical knowledge. 


\section{References}

1. Papadopoulos NG, Barnes P, Canonica GW et al. The Evolving Algorithm of Biological Selection in Severe Asthma. Allergy. 2020;75, 1555-1563.

2. Ortega HG, Liu MC, Pavord ID, Brusselle GG, FitzGerald JM, Chetta A, et al. Mepolizumab Treatment in Patients with Severe Eosinophilic Asthma. N Engl J Med. 2014;371(13):11981207.

3. Haldar P, Brightling CE, Hargadon B, et al. Mepolizumab and Exacerbations of Refractory Eosinophilic Asthma. New En. 2009;360(10):973-84.

4. Pavord ID, Korn S, Howarth P et al. Mepolizumab for severe eosinophilic asthma (DREAM): A multicentre, double-blind, placebo-controlled trial. Lancet. 2012;380(9842):651-9.

5. Shrimanker R, Pavord ID, Yancey $S$ et al. Exacerbations of severe asthma in patients treated with mepolizumab. Eur Respir J. 2018;52(6):1801127.

6. Chupp GL, Bradford ES, Albers FC et al. Efficacy of mepolizumab add-on therapy on healthrelated quality of life and markers of asthma control in severe eosinophilic asthma (MUSCA): a randomised, double-blind, placebo-controlled, parallel-group, multicentre, phase $3 \mathrm{~b}$ trial. Lancet Respir Med. 2017;5(5):390-400.

7. Shrimanker R, Keene O, Bratton DJ, Yancey S, Heaney L, Pavord ID. Characterisation of Exacerbations of Severe Eosinophilic Asthma on Mepolizumab Compared to Placebo. In: American Thoracic Society International Conference Meetings Abstracts American Thoracic Society International Conference Meetings Abstracts. American Thoracic Society; 2019. p. A2671-A2671.

8. Global Initiative for Asthma. Pocket Guide for Asthma Management and Prevention. Glob Initiat Asthma. 2019;1-32. URL: https://ginasthma.org/reports/ Accessed 03 Mar 2020

9. NICE 2017. 1 Recommendations | Mepolizumab for treating severe refractory eosinophilic asthma | Guidance | NICE. 2017 URL: https://www.nice.org.uk/guidance/TA431/chapter/1Recommendations Accessed 21 Jan 2020

10. Consortium SS medicines. mepolizumab (Nucala) [Internet]. Scottish medicines consortium. 2016. URL: https://www.scottishmedicines.org.uk/medicines-advice/mepolizumab-nucalafullsubmission-114916/ Accessed 22 Mar 2020.

11. Juniper EF, O'Byrne PM, Guyatt GH, Ferrie PJ, King DR. Development and validation of a questionnaire to measure asthma control. Eur Respir J. 1999;14(4):902-7.

12. Juniper EF, Guyatt GH, Cox FM, Ferrie PJ, King DR. Development and validation of the Mini Asthma Quality of Life Questionnaire. Eur Respir J. 1999;14(1):32-8.

13. Jones PW, Quirk FH, Baveystock CM. The St George's Respiratory Questionnaire. Respir Med. 1991;85:25-31.

14. SIGN 153 - British guideline on the management of asthma A national clinical guideline 2016. URL: www.sign.ac.uk/pdf/sign50eqia.pdf. Accessed 21 Mar 2020.

15. Miller MR, Hankinson J, Brusasco V et al. Standardisation of spirometry. Eur Respir J (2005) 26, 319-338.

16. Quanjer PH, Stanojevic S, Cole TJ et al. Multi-ethnic reference values for spirometry for the 395-yr age range: The global lung function 2012 equations. Eur Respir J. 2012;40(6):1324-43.

17. Bafadhel M, McKenna S, Terry $S$ et al. Acute exacerbations of chronic obstructive pulmonary disease: Identification of biologic clusters and their biomarkers. Am J Respir Crit Care Med. 2011;184(6):662-71.

18. Bafadhel M, Haldar K, Barker B et al. Airway bacteria measured by quantitative polymerase chain reaction and culture in patients with stable COPD: Relationship with neutrophilic airway inflammation, exacerbation frequency, and lung function. Int J COPD. 2015;10:1075-83.

19. GINA. GLOBAL INITIATIVE FOR ASTHMA A GINA Pocket Guide For Health Professionals DIFFICULT-TO-TREAT \& SEVERE ASTHMA in adolescent and adult patients Diagnosis and Management A GINA Pocket Guide For Health Professionals DIFFICULT-TO-TREAT \& SEVERE ASTHMA in adole. URL: www.ginasthma.org Accessed 13 Mar 2020 
20. Pavord ID, Bleeker ER, Buhl R et al. Response to mepolizumab treatment is sustained across 4weekly dosing periods. ERJ Open. 2020 6: 00068-2020; DOI: 10.1183/23120541.00068-2020 (In press)

21. Ghebre MA, Pang PH, Diver Set al. Biological exacerbation clusters demonstrate asthma and chronic obstructive pulmonary disease overlap with distinct mediator and microbiome profiles. J Allergy Clin Immunol. 2018;141(6):2027-2036.

22. Heaney LG, Busby J, Bradding $P$ et al. Remotely monitored therapy and nitric oxide suppression identifies nonadherence in severe asthma. Am J Respir Crit Care Med. 2019;199(4):454-64.

23. Sehmi R, Smith SG, Kjarsgaard M et al. Role of local eosinophilopoietic processes in the development of airway eosinophilia in prednisone-dependent severe asthma. Clin Exp Allergy. 2016;46(6):793-802.

24. Mukherjee $M$, Bulir DC, Radford $K$ et al. Sputum autoantibodies in patients with severe eosinophilic asthma. J Allergy Clin Immunol. 2018;141(4):1269-79.

25. Ravin KA, Loy M. The eosinophil in infection. Clin Rev Allergy Immunol. 2015;50(2):214-27.

26. Shamri R, Xenakis JJ, Spencer LA. Eosinophils in innate immunity: An evolving story. Cell and Tissue Research 2011;343, 57-83.

27. Gleich GJ, Klion AD, Lee JJ, Weller PF. The consequences of not having eosinophils . Allergy: European Journal of Allergy and Clinical Immunology 2013;68, 829-835.

28. Zhao L, Zhang Y-P, Yang $X$, Liu X. Eosinopenia is associated with greater severity in patients with coronavirus disease 2019. Allergy. 2020;00:1-3.

29. Li Q, Ding X, Xia G et al. Eosinopenia and elevated C-reactive protein facilitate triage of COVID19 patients in fever clinic: A retrospective case-control study. EClinicalMedicine. 2020;23:100375.

30. Lindsley AW, Schwartz JT, Rothenberg ME. Eosinophil responses during COVID-19 infections and coronavirus vaccination. J Allergy Clin Immunol. 2020;146, 1-7.

31. Poznanski SM, Mukherjee $\mathrm{M}, \mathrm{Zhao} \mathrm{N}$ et al. Asthma exacerbations on benralizumab are largely non-eosinophilic. Allergy 2020;00, 1-5.

32. Benralizumab Exacerbation Study - Full Text View - ClinicalTrials.gov. URL: https://clinicaltrials.gov/ct2/show/NCT04102800. Accessed 10072020

33. Zeiger RS, Schatz M, Li Q et al. High Blood Eosinophil Count Is a Risk Factor for Future Asthma Exacerbations in Adult Persistent Asthma. J Allergy Clin Immunol Pract. 2014;2(6):741-750.

34. Price DB, Rigazio A, Campbell JD et al. Blood eosinophil count and prospective annual asthma disease burden: A UK cohort study. Lancet Respir Med. 2015;3(11):849-58.

35. Pavord ID, Brightling CE, Woltmann G, Wardlaw AJ. Non-eosinophilic corticosteroid inresponsive asthma. Lancet 1999; 353:2213-14

36. Woodruff PG, Modrek B, Choy D et al. Am J Respir Crit Care Med 2009;180;(5) 388-95

37. McGrath KW, Icitovic N, Boushey H et al. Am J Resp Crit Care Med 2012; 185(6)612-9

38. McDowell PJ, Heaney LG. Different phenotypes and Endotypes drive heterogeneity in asthma. Allergy. 2019 75;(2)302-310

39. Gibson PG, Yang IA, Upham JW et al. Effect of azithromycin on asthma exacerbations and quality of life in adults with persistent uncontrolled asthma (AMAZES): a randomised, doubleblind, placebo-controlled trial. Lancet. 2017;390(10095):659-668. doi:10.1016/S01406736(17)31281-3 
Table 1: Participant characteristics when clinically stable and established on mepolizumab ( $\geq 12$ weeks mepolizumab treatment).

\begin{tabular}{|c|c|c|}
\hline \multicolumn{3}{|l|}{ Participant characteristics $(\mathrm{N}=140)$} \\
\hline Age (years) & & $55 \cdot 47(11.5)$ \\
\hline Male & & $73 / 140(52.1 \%)$ \\
\hline Maintenance prednisolone $(\mathrm{mg})$ & & $102 / 140(74 \cdot 5 \%)$ \\
\hline Prednisolone Dose (mg) (N=102) & & $10 \cdot 0(5 \cdot 0,10 \cdot 0)$ \\
\hline ICS dose (BDP $\mu \mathrm{g}$ equivalent) & & $2000(2000,2000)$ \\
\hline Combined ICS-LABA & & $140(100 \%)$ \\
\hline Inhaled anti-muscarinic* & & $77 / 140(55.0 \%)$ \\
\hline Leukotriene receptor antagonist* & & $74 / 140(52 \cdot 9 \%)$ \\
\hline Oral Theophylline & & $57 / 140(40 \cdot 7 \%)$ \\
\hline $\begin{array}{c}\text { ACQ-5 Total Score } \\
\text { ACQ-5 } \leq 0.75 \\
\text { ACQ-5 } \geq 1.5\end{array}$ & & $\begin{array}{c}2 \cdot 0(1 \cdot 0,3 \cdot 0) \\
24 / 135(17 \cdot 8 \%) \\
83 / 135(61 \cdot 9 \%)\end{array}$ \\
\hline Mini-AQLQ Total Score & & $4 \cdot 6(3 \cdot 3,6 \cdot 4)$ \\
\hline SGRQ Total Score & & $46 \cdot 1(21 \cdot 5,63 \cdot 3)$ \\
\hline Total WCC $\left(10^{\wedge} 9 / \mathrm{L}\right)$ & & $8 \cdot 5(7 \cdot 1,10 \cdot 2)$ \\
\hline Blood Neutrophils $\left(10^{\wedge} 9 / \mathrm{L}\right)$ & & $5 \cdot 6(4 \cdot 5,8 \cdot 1)$ \\
\hline $\begin{array}{l}\text { Blood Eosinophils }(\text { cells } / \mu \mathrm{L}) \\
\geq 100 \text { cells } / \mu \mathrm{L}\end{array}$ & & $\begin{array}{c}50(30,90) \\
31 / 135(23 \cdot 1 \%)\end{array}$ \\
\hline $\mathrm{CRP}(\mathrm{mg} / \mathrm{L})$ & & $4 \cdot 0(1 \cdot 8,6 \cdot 0)$ \\
\hline $\mathrm{FEV}_{1}(\%$ Predicted $)$ & & $71 \cdot 8(20 \cdot 9)$ \\
\hline FVC (\% Predicted) & & $86 \cdot 9(18 \cdot 3)$ \\
\hline \begin{tabular}{|r|} 
FENO $(\mathrm{ppb})$ \\
FENO $\leq 20$ \\
FENO $\geq 50$ \\
\end{tabular} & & $\begin{array}{l}32 \cdot 5(19 \cdot 0,66 \cdot 0) \\
35 / 134(26 \cdot 1 \%) \\
50 / 134(37 \cdot 3 \%)\end{array}$ \\
\hline \multicolumn{3}{|l|}{ Sputum } \\
\hline $\begin{array}{l}\text { Sputum Neutrophils } \% \text { of cells } \\
\geq 65 \%\end{array}$ & $\mathrm{~N}=75$ & $\begin{array}{c}43 \cdot 8(26 \cdot 8,68 \cdot 7) \\
20(26.6 \%)\end{array}$ \\
\hline Sputum Lymphocyte \% of cells & $\mathrm{N}=75$ & $0 \cdot 0(0 \cdot 0,0 \cdot 9)$ \\
\hline $\begin{array}{l}\text { Sputum Eosinophils } \% \text { of cells } \\
\geq 2 \%\end{array}$ & $\mathrm{~N}=75$ & $\begin{array}{c}1 \cdot 3(0 \cdot 2,5 \cdot 7) \\
31 / 75(41.3 \%) \\
\end{array}$ \\
\hline Sputum Macrophages \% of cells & $\mathrm{N}=75$ & $35 \cdot 7(18 \cdot 4,61 \cdot 0)$ \\
\hline Virus positive on PCR & $\mathrm{N}=69$ & $8 / 69(11.6 \%)$ \\
\hline Total 16s Copies/ml & $\mathrm{N}=69$ & $9 \cdot 2 \times 10^{\wedge} 8\left(2 \cdot 3 \times 10^{\wedge} 8,2 \cdot 2 \times 10^{\wedge} 9\right)$ \\
\hline Any qPCR Bacteria Positive above threshold of detection & $\mathrm{N}=69$ & $39 / 69(56 \cdot 5 \%)$ \\
\hline Any Bacteria Positive $\left(\geq 10^{\wedge} 6\right.$ genome copies $\left./ \mathrm{ml}\right)$ & $\mathrm{N}=69$ & $25 / 69(36 \cdot 2 \%)$ \\
\hline Moraxella catarrhalis $\left(\geq 10^{\wedge} 6\right.$ genome copies $\left./ \mathrm{ml}\right)$ & $\mathrm{N}=69$ & $4 / 69(5 \cdot 8 \%)$ \\
\hline Haemophilus influenzae $\left(\geq 10^{\wedge} 6\right.$ genome copies $\left./ \mathrm{ml}\right)$ & $\mathrm{N}=69$ & $10 / 69(14 \cdot 5 \%)$ \\
\hline Streptococcus pneumonia $\left(\geq 10^{\wedge} 6\right.$ genome copies $\left./ \mathrm{ml}\right)$ & $\mathrm{N}=69$ & $13 / 69(18 \cdot 8 \%)$ \\
\hline $\begin{array}{c}\text { Count of Bacteria Positive }\left(\geq 10^{\wedge} 6 \text { genome copies } / \mathrm{ml}\right) \\
0 \text { bacteria specific qPCR }>10^{\wedge} 6 \text { Copies } / \mathrm{ml} \\
1 \text { bacteria specific qPCR }>10^{\wedge} 6 \text { Copies } / \mathrm{ml} \\
2 \text { bacteria specific qPCR }>10^{\wedge} 6 \text { Copies } / \mathrm{ml} \\
\end{array}$ & $\mathrm{N}=69$ & $\begin{array}{c}44 / 69(63 \cdot 8 \%) \\
23 / 69(33 \cdot 3 \%) \\
2 / 69(2 \cdot 9 \%)\end{array}$ \\
\hline Any Virus or Bacteria $\left(\geq 10^{\wedge} 6\right.$ genome copies $\left./ \mathrm{ml}\right)$ & $\mathrm{N}=69$ & $30 / 69(43 \cdot 5 \%)$ \\
\hline
\end{tabular}


Parainfluenza 4 and Coronavirus. * These add on therapies have not been studied in severe asthma populations. 
Table 2. First exacerbation per participant with sputum: low sputum eosinophils $(<2 \%)$ versus high sputum eosinophils $(\geq 2 \%)$.

\begin{tabular}{|c|c|c|c|c|}
\hline \multicolumn{2}{|l|}{ First assessed exacerbation with sputum } & \multirow{2}{*}{$\begin{array}{c}\text { Sputum Eosinophils } \\
<\mathbf{2 \%}(\mathbf{n}=\mathbf{2 4})\end{array}$} & \multirow{2}{*}{$\begin{array}{c}\text { Sputum } \\
\text { Eosinophils } \\
\geq \mathbf{2 \%}(\mathbf{n}=\mathbf{2 1}) \\
0 \cdot 7(0 \cdot 5,0 \cdot 8)\end{array}$} & \multirow{2}{*}{$\frac{\mathbf{p}}{0 \cdot 20}$} \\
\hline $\begin{array}{l}\text { Time between mepolizumab Initiation and } \\
\text { Exacerbation (Years) }\end{array}$ & $\mathrm{N}=45$ & & & \\
\hline $\begin{array}{l}\text { Days since last mepolizumab } \\
\text { administration }\end{array}$ & $\mathrm{N}=45$ & $14 \cdot 5(6 \cdot 0,26 \cdot 5)$ & $14 \cdot 0(6 \cdot 0,24 \cdot 0)$ & 0.97 \\
\hline Maintenance prednisolone at exacerbation & $\mathrm{N}=45$ & $16 / 24(66 \cdot 7 \%)$ & $13 / 21(61 \cdot 9 \%)$ & $0 \cdot 74$ \\
\hline $\begin{array}{l}\text { Maintenance prednisolone dose at } \\
\text { exacerbation }\end{array}$ & $\mathrm{N}=29$ & $6 \cdot 9(4 \cdot 5,10 \cdot 0)$ & $5 \cdot 0(5 \cdot 0,10 \cdot 0)$ & 0.69 \\
\hline \multicolumn{5}{|l|}{ Symptoms at exacerbation } \\
\hline New or Increased Breathlessness & $\mathrm{N}=45$ & $22 / 24(91 \cdot 7 \%)$ & $21 / 21(100 \cdot 0 \%)$ & $0 \cdot 18$ \\
\hline Decrease in Exercise Tolerance & $\mathrm{N}=44$ & $22 / 23(95 \cdot 7 \%)$ & $14 / 21(66 \cdot 7 \%)$ & $0 \cdot 013$ \\
\hline Cough & $\mathrm{N}=45$ & $24 / 24(100 \cdot 0 \%)$ & $18 / 21(85 \cdot 7 \%)$ & 0.055 \\
\hline Change in Sputum Volume & $\mathrm{N}=45$ & $23 / 24(95 \cdot 8 \%)$ & $17 / 21(81 \cdot 0 \%)$ & $0 \cdot 11$ \\
\hline Increased Sputum Purulence & $\mathrm{N}=45$ & $19 / 24(79 \cdot 2 \%)$ & $11 / 21(52 \cdot 4 \%)$ & $0 \cdot 057$ \\
\hline Increased Nocturnal Wakening & $\mathrm{N}=45$ & $22 / 24(91 \cdot 7 \%)$ & $17 / 21(81 \cdot 0 \%)$ & $0 \cdot 29$ \\
\hline Wheeze & $\mathrm{N}=45$ & $18 / 24(75 \cdot 0 \%)$ & $17 / 21(81 \cdot 0 \%)$ & 0.63 \\
\hline Preceding Coryzal Symptoms & $\mathrm{N}=45$ & $15 / 24(62 \cdot 5 \%)$ & $9 / 21(42.9 \%)$ & $0 \cdot 19$ \\
\hline Fevers & $\mathrm{N}=45$ & $12 / 24(50 \cdot 0 \%)$ & $5 / 21(23 \cdot 8 \%)$ & $0 \cdot 071$ \\
\hline Haemoptysis & $\mathrm{N}=45$ & $1 / 24(4 \cdot 2 \%)$ & $1 / 21(4 \cdot 8 \%)$ & $0 \cdot 92$ \\
\hline \multicolumn{5}{|l|}{ Physiological measurements } \\
\hline FENO (ppb) & $\mathrm{N}=44$ & $24 \cdot 0(16 \cdot 0,45 \cdot 0)$ & $57 \cdot 0(30 \cdot 0,111 \cdot 0)$ & $<0 \cdot 001$ \\
\hline PEF (L/min) & $\mathrm{N}=43$ & $359 \cdot 2(124 \cdot 7)$ & $305 \cdot 1(88 \cdot 8)$ & $0 \cdot 11$ \\
\hline $\mathrm{FEV}_{1}(\%$ Predicted $)$ & $\mathrm{N}=44$ & $71 \cdot 5(21 \cdot 4)$ & $55 \cdot 6(15 \cdot 3)$ & $0 \cdot 0075$ \\
\hline $\mathrm{FEV}_{1} / \mathrm{FVC}$ & $\mathrm{N}=44$ & $67 \cdot 8(9 \cdot 0)$ & $57 \cdot 5(13 \cdot 5)$ & $0 \cdot 0043$ \\
\hline ACQ-5 Total Score & $\mathrm{N}=45$ & $3 \cdot 5(2 \cdot 1,3 \cdot 9)$ & $2 \cdot 8(2 \cdot 0,3 \cdot 6)$ & $0 \cdot 19$ \\
\hline Unscheduled Visit Clinical Diagnosis & $\mathrm{N}=44$ & & & 0.04 \\
\hline Non-Infective Exacerbation Of Asthma & & $3 / 24(12 \cdot 5 \%)$ & $10 / 20(50 \cdot 0 \%)$ & \\
\hline Viral Upper Respiratory Tract Infection & & $8 / 24(33 \cdot 3 \%)$ & $5 / 20(25 \cdot 0 \%)$ & \\
\hline Viral Lower Respiratory Tract Infection & & $5 / 24(20 \cdot 8 \%)$ & $3 / 20(15 \cdot 0 \%)$ & \\
\hline $\begin{array}{l}\text { Bacterial Upper Respiratory Tract } \\
\text { Infection }\end{array}$ & & $4 / 24(16 \cdot 7 \%)$ & $0 / 20(0 \cdot 0 \%)$ & \\
\hline $\begin{array}{l}\text { Bacterial Lower Respiratory Tract } \\
\text { Infection }\end{array}$ & & $3 / 24(12 \cdot 5 \%)$ & $0 / 20(0.0 \%)$ & \\
\hline Pneumonia & & $1 / 24(4 \cdot 2 \%)$ & $0 / 20(0 \cdot 0 \%)$ & \\
\hline Sinusitis & & $0 / 24(0 \cdot 0 \%)$ & $1 / 20(5 \cdot 0 \%)$ & \\
\hline Vocal Cord Dysfunction & & $0 / 24(0 \cdot 0 \%)$ & $1 / 20(5 \cdot 0 \%)$ & \\
\hline \multicolumn{5}{|l|}{ Unscheduled Visit Treatment } \\
\hline High Dose OCS Initiated & $\mathrm{N}=45$ & $14 / 24(58 \cdot 3 \%)$ & $11(52 \cdot 4 \%)$ & $0 \cdot 69$ \\
\hline Antibiotics Initiated & $\mathrm{N}=45$ & $12 / 24(50 \cdot 0 \%)$ & $4(19 \cdot 0 \%)$ & $0 \cdot 031$ \\
\hline Hospital Admission & $\mathrm{N}=45$ & $1 / 24(4 \cdot 2 \%)$ & $0(0 \cdot 0 \%)$ & $0 \cdot 34$ \\
\hline Further Medical Assessment Required & & & & 0.29 \\
\hline $\mathrm{Gp}$ & & $1 / 4(25 \cdot 0 \%)$ & $1 / 3(33 \cdot 3 \%)$ & \\
\hline Hospital Admission & & $2 / 4(50 \cdot 0 \%)$ & $0 / 3(0 \cdot 0 \%)$ & \\
\hline Further Study Visit & & $0 / 4(0.0 \%)$ & $1 / 3(33 \cdot 3 \%)$ & \\
\hline Asthma Nurse & & $1 / 4(25 \cdot 0 \%)$ & $0 / 3(0 \cdot 0 \%)$ & \\
\hline \multicolumn{5}{|l|}{ Haematology } \\
\hline Blood Neutrophils $\left(10^{\wedge} 9 / \mathrm{L}\right)$ & $\mathrm{N}=45$ & $6 \cdot 7(4 \cdot 7,8 \cdot 8)$ & $5 \cdot 1(4 \cdot 2,6 \cdot 8)$ & $0 \cdot 13$ \\
\hline Blood Eosinophils (cells/ $\mu \mathrm{L})$ & $\mathrm{N}=45$ & $30(10,50)$ & $70(50,90)$ & $<0 \cdot 001$ \\
\hline CRP (mg/L) & $\mathrm{N}=44$ & $15 \cdot 0(5 \cdot 0,24 \cdot 0)$ & $2 \cdot 3(1 \cdot 5,4 \cdot 9)$ & $<0 \cdot 001$ \\
\hline \multicolumn{5}{|l|}{ Sputum } \\
\hline Sputum Neutrophils $\%$ of cells & $\mathrm{N}=45$ & $89 \cdot 8(71 \cdot 6,94 \cdot 9)$ & $37 \cdot 1(28 \cdot 6,54 \cdot 2)$ & $<0 \cdot 001$ \\
\hline Sputum Lymphocyte $\%$ of cells & $\mathrm{N}=45$ & $0 \cdot 0(0 \cdot 0,0 \cdot 3)$ & $1 \cdot 5(0 \cdot 2,2 \cdot 8)$ & $0 \cdot 0040$ \\
\hline Sputum Eosinophils \% of cells & $\mathrm{N}=45$ & $0 \cdot 4(0 \cdot 2,0 \cdot 8)$ & $10 \cdot 4(4 \cdot 5,20 \cdot 6)$ & $<0 \cdot 001$ \\
\hline Sputum Macrophages \% of cells & $\mathrm{N}=45$ & $8 \cdot 5(4 \cdot 1,25 \cdot 6)$ & $36 \cdot 0(21 \cdot 9,55 \cdot 6)$ & $<0 \cdot 001$ \\
\hline Virus positive on PCR & $\mathrm{N}=33$ & $9 / 20(45 \cdot 0 \%)$ & $3 / 13(23 \cdot 1 \%)$ & $0 \cdot 20$ \\
\hline
\end{tabular}




\begin{tabular}{|c|c|c|c|c|}
\hline Total 16s Copies/ml & $\mathrm{N}=33$ & $\begin{array}{c}1 \cdot 0 \times 10^{\wedge} 9 \\
\left(3 \cdot 9 \times 10^{\wedge} 8,1 \cdot 8 \times 10^{\wedge} 9\right)\end{array}$ & $\begin{array}{c}9 \cdot 7 \times 10^{\wedge} 8 \\
\left(6 \cdot 0 \times 10^{\wedge} 8,1 \cdot 8 \times 10^{\wedge} 9\right. \\
) \\
\end{array}$ & $0 \cdot 71$ \\
\hline $\begin{array}{l}\text { Any qPCR Bacteria Positive above } \\
\text { threshold of detection }\end{array}$ & $\mathrm{N}=33$ & $14 / 20(70 \cdot 0 \%)$ & $8 / 13(61 \cdot 5 \%)$ & $0 \cdot 61$ \\
\hline $\begin{array}{l}\text { Any Bacteria Positive }\left(\geq 10^{\wedge} 6 \text { genome }\right. \\
\text { copies } / \mathrm{ml})\end{array}$ & $\mathrm{N}=33$ & $10 / 20(50 \cdot 0 \%)$ & $3 / 13(23 \cdot 1 \%)$ & $0 \cdot 12$ \\
\hline $\mathrm{MC}\left(\geq 10^{\wedge} 6\right.$ genome copies $\left./ \mathrm{ml}\right)$ & $\mathrm{N}=33$ & $4 / 20(20 \cdot 0 \%)$ & $0 / 13(0 \cdot 0 \%)$ & 0.085 \\
\hline $\mathrm{HI}\left(\geq 10^{\wedge} 6\right.$ genome copies $\left./ \mathrm{ml}\right)$ & $\mathrm{N}=33$ & $3 / 20(15 \cdot 0 \%)$ & $0 / 13(0 \cdot 0 \%)$ & $0 \cdot 14$ \\
\hline SP $\left(\geq 10^{\wedge} 6\right.$ genome copies $\left./ \mathrm{ml}\right)$ & $\mathrm{N}=33$ & $4 / 20(20 \cdot 0 \%)$ & $3 / 13(23 \cdot 1 \%)$ & $0 \cdot 83$ \\
\hline $\begin{array}{c}\text { Count of Bacteria Positive }>10^{\wedge} 6 \text { Copies } / \mathrm{ml} \\
0 \text { bacteria specific qPCR }>10^{\wedge} 6 \text { Copies } / \mathrm{ml} \\
1 \text { bacteria specific qPCR }>10^{\wedge} 6 \text { Copies } / \mathrm{ml} \\
2 \text { bacteria specific qPCR }>10^{\wedge} 6 \text { Copies } / \mathrm{ml} \\
\end{array}$ & $\mathrm{N}=33$ & $\begin{array}{c}10 / 20(50 \cdot 0 \%) \\
9 / 20(45 \cdot 0 \%) \\
1 / 20(5 \cdot 0 \%) \\
\end{array}$ & $\begin{array}{c}10 / 13(76 \cdot 9 \%) \\
3 / 13(23 \cdot 1 \%) \\
0 / 13(0 \cdot 0 \%) \\
\end{array}$ & $0 \cdot 27$ \\
\hline $\begin{array}{l}\text { Any Virus or Bacteria }\left(\geq 10^{\wedge} 6 \text { genome }\right. \\
\text { copies } / \mathrm{ml})\end{array}$ & $\mathrm{N}=33$ & $15 / 20(75 \cdot 0 \%)$ & $5 / 13(38 \cdot 5 \%)$ & $0 \cdot 036$ \\
\hline
\end{tabular}




\section{Figure Legends:}

Figure 1. Subject recruitment and exacerbations.

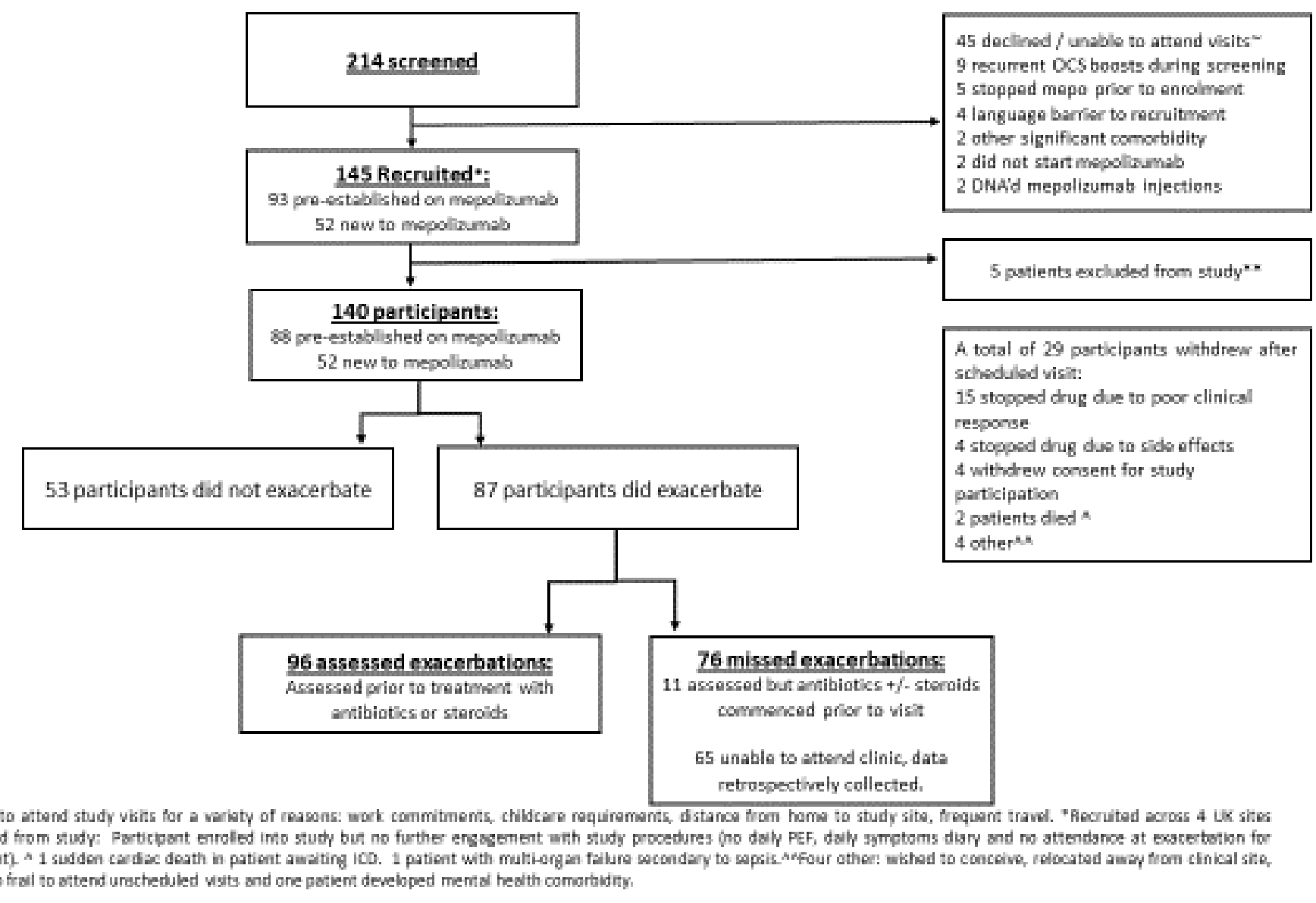


Figure 2: Comparison of change in peak expiratory flow and daily symptoms diary the fourteen days before and after exacerbation for missed and assessed exacerbations.

Figure 2.1 Mean change with $95 \% \mathrm{Cl}$ in daily peak expiratory flow for the 14 days before and 14 days after exacerbation for assessed and missed exacerbations.

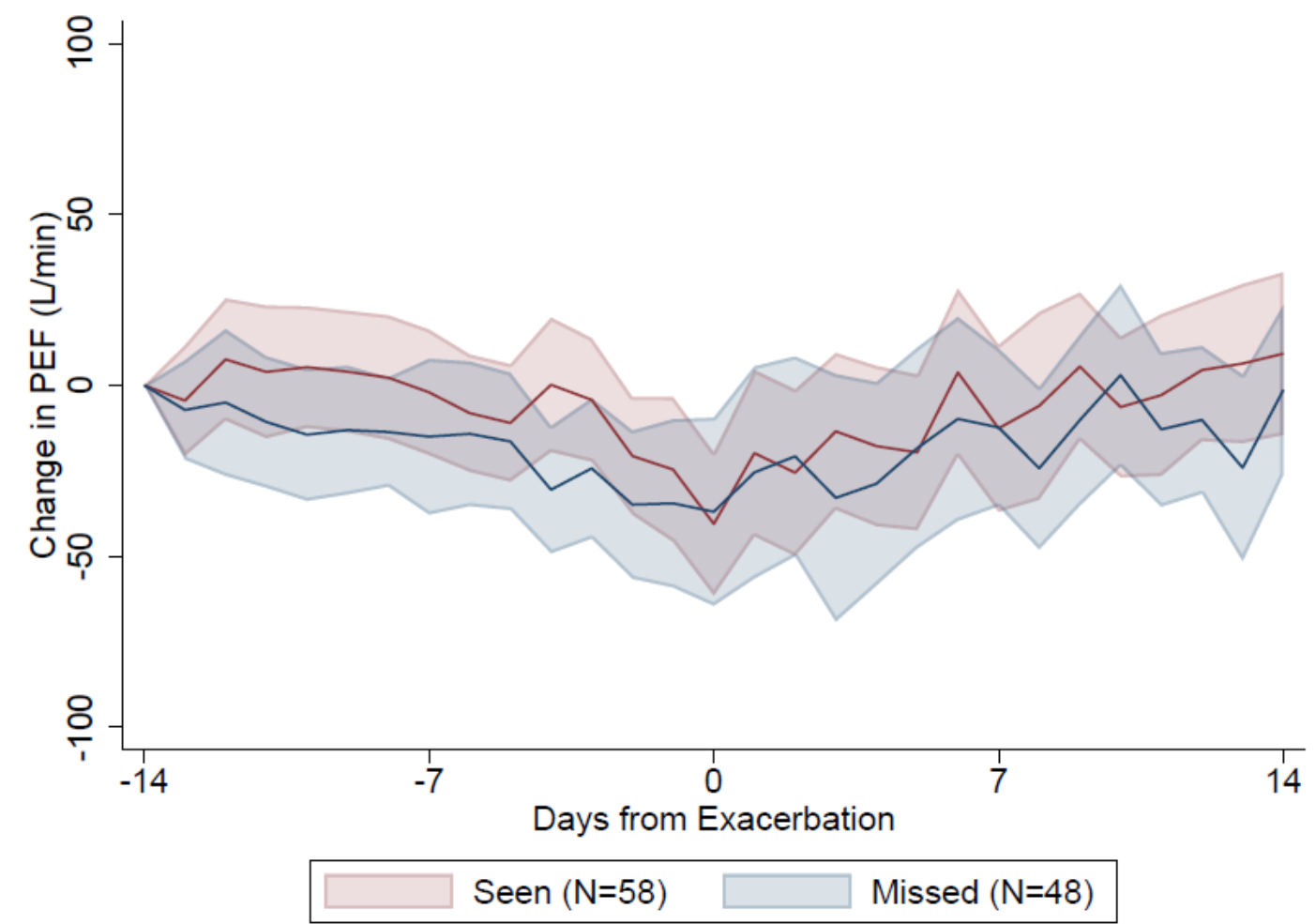


Figure 2.2 Mean change with $95 \% \mathrm{Cl}$ in daily asthma symptom severity score for the 14 days before and 14 days after exacerbation for assessed) and missed exacerbations. Asthma symptoms score from 0 (no symptoms) to 6 (severe symptoms).

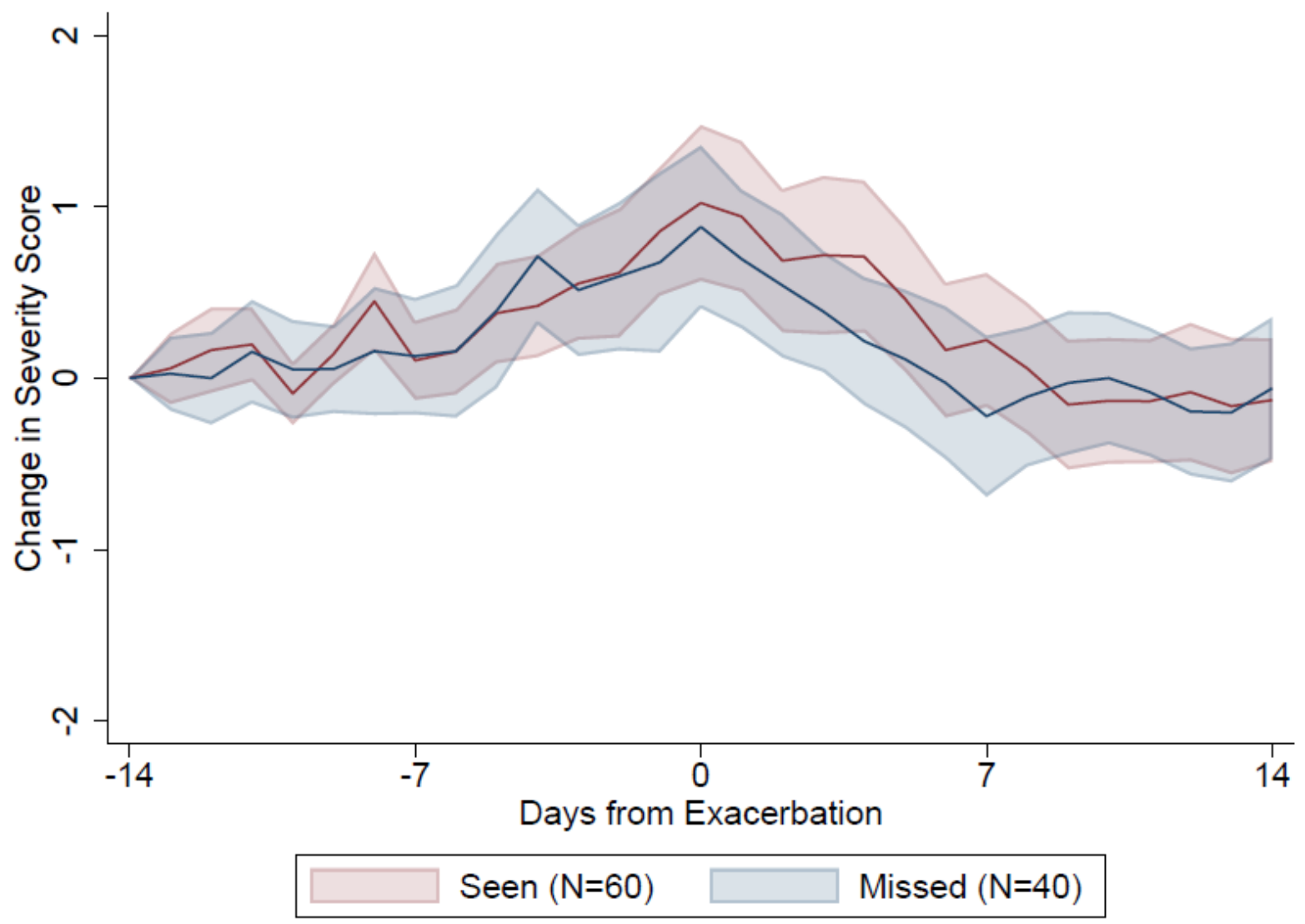


Figure 2.3 Mean change with $95 \% \mathrm{Cl}$ in number of night awakenings requiring rescue medication for the 14 days before and 14 days after exacerbation for assessed and missed exacerbations.

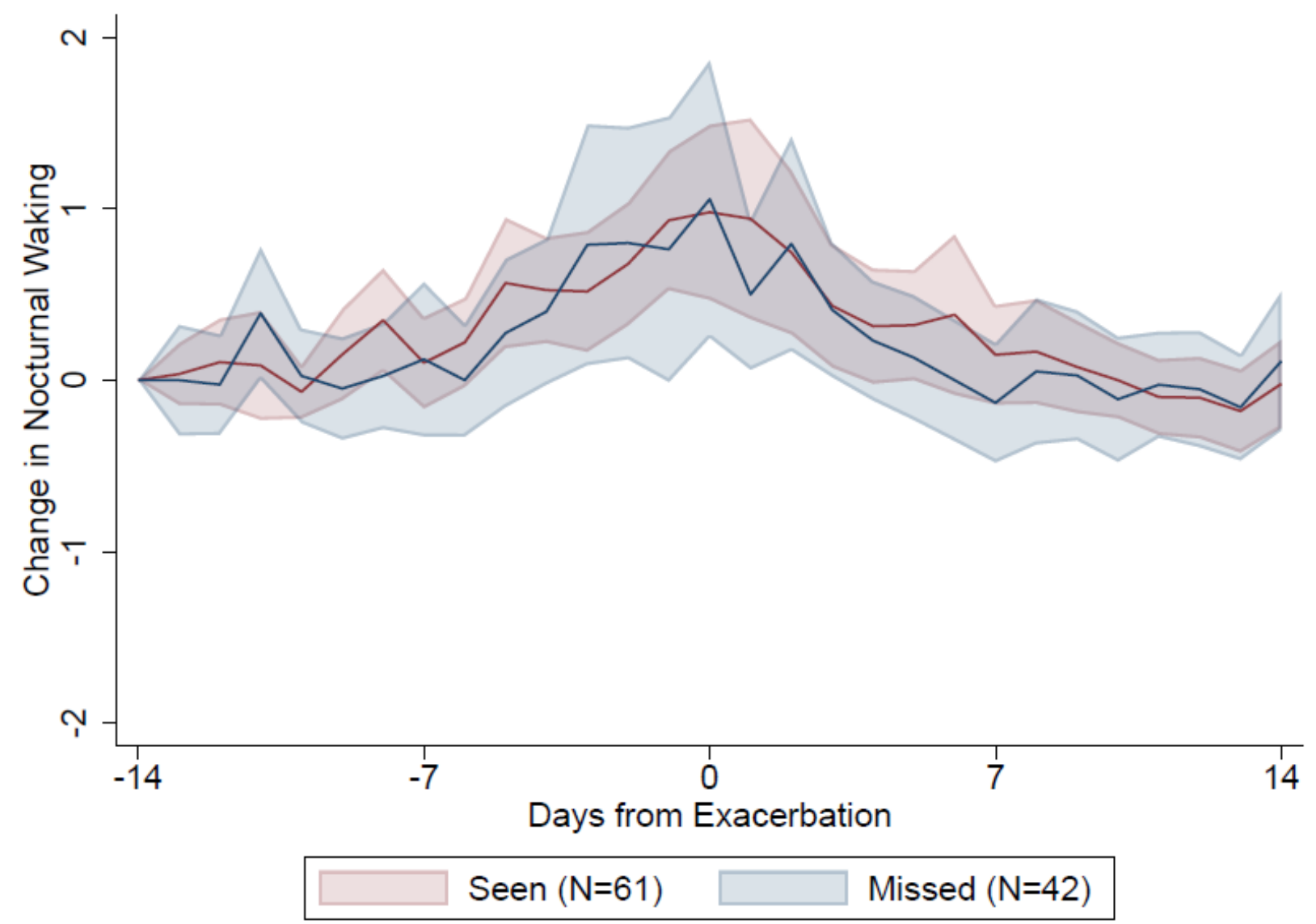


Figure 2.4 Mean change with $95 \% \mathrm{Cl}$ in rescue medication requirements for the 14 days before and 14 days after exacerbation for assessed and missed exacerbations.

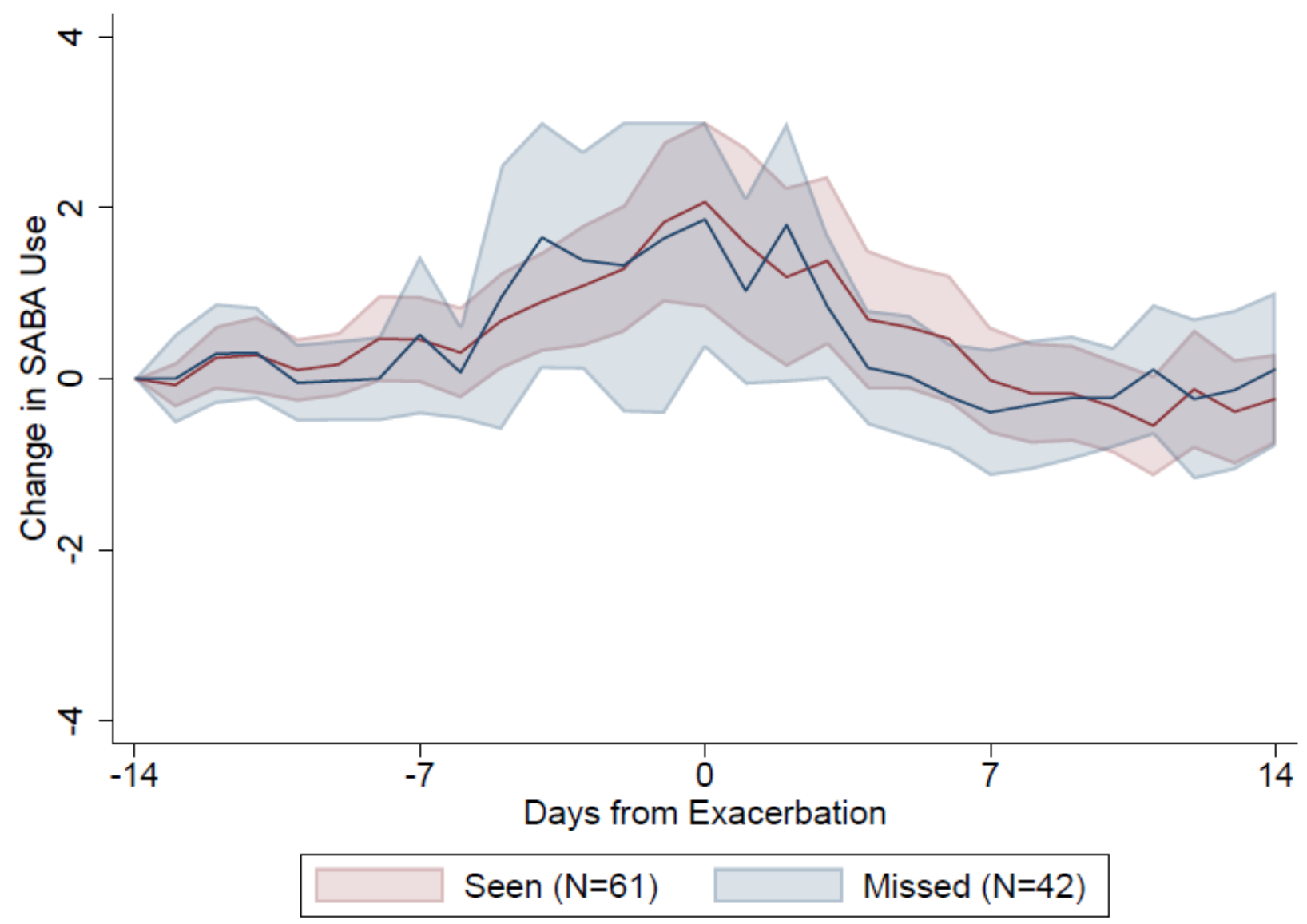


Figure 3. FeNO as a predictor of sputum eosinophilia: a FeNO 20ppb or less was associated with low sputum eosinophils in sputum (14/57 exacerbations had FeNO $\leq 20 \mathrm{ppb}$, all had a sputum eosinophil count of $<2 \%$, a positive predictive value of $100 \%$ ). FeNO of $50 \mathrm{ppb}$ or greater was associated with high sputum eosinophils (20/26 exacerbations with FeNO of $\geq 50 \mathrm{ppb}$ had an eosinophil count $\geq 2 \%$, a positive

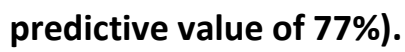

\section{FeNO and Sputum eosinophils at exacerbation.}

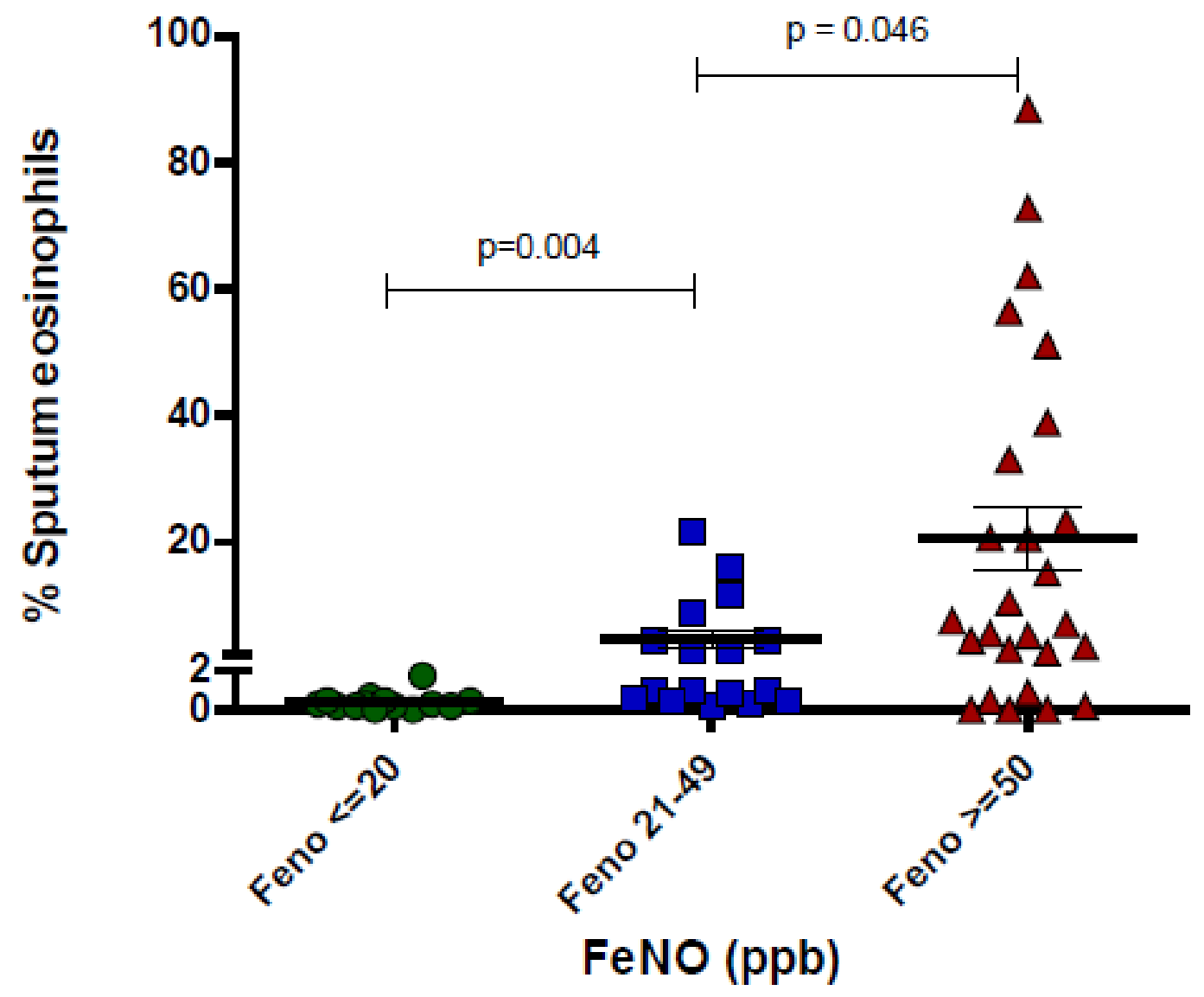




\section{Inflammatory profile of Mepolizumab EXacerbations in participants with severe refractory eosinophilic asthma (the MEX study).}

PJ McDowell ${ }^{1}$, S Diver ${ }^{2}$, F Yang ${ }^{3}$, K Borg ${ }^{4}, \mathrm{~J} \mathrm{Busby}^{5}$, V Brown ${ }^{1}$, Shrimanker R ${ }^{4}, \mathrm{C}$ Cox $^{1}, \mathrm{CE}$

Brightling $^{3}$, R Chaudhuri ${ }^{2}$, ID Pavord ${ }^{4}$, LG Heaney ${ }^{1}$ on behalf of the Medical Research Council:

Refractory Asthma Stratification Programme (RASP-UK Consortium).

\section{Online supplement:}

\section{NICE and SMC guidance on eligibility to receive mepolizumab treatment:}

A) National Institute for Health and Care Excellence (UK): ${ }^{1}$

Mepolizumab treatment can be considered in severe, refractory eosinophilic asthmatics in addition to optimised therapy when:

- Blood eosinophil count is 300 cells/microliter or more in the previous 12 months and

- The person has agreed to and followed the optimised standard treatment plan and

- Has had 4 or more asthma exacerbations requiring systemic corticosteroids in the previous 12 months or

- Has had continuous oral corticosteroids of at least the equivalent of prednisolone $5 \mathrm{mg} / \mathrm{day}$ over the previous 6 months.

B) Scottish medicines consortium (UK): ${ }^{2}$

Indication for mepolizumab treatment as an add-on treatment for severe refractory eosinophilic asthma in adult patients.

- Patients who have eosinophils of at least 150 cells per microlitre $\left(0 \cdot 15 \times 10^{9} / \mathrm{L}\right)$ at initiation of treatment

- Patients who have had at least four asthma exacerbations in the preceding year or

- Patients who are receiving maintenance treatment with oral corticosteroids.

Inclusion and exclusion criteria for the inflammatory profile of mepolizumab exacerbations in participants with severe refractory eosinophilic asthma study:

\section{Inclusion:}

Participants must meet the following criteria at visit 1 for study entry (participants can be rescreened for study entry up to 3 times):

1. Age $\geq 18$ and $\leq 80$ years at Visit 1

2. Able and willing to provide written informed consent and to comply with the study protocol including being able to contact the clinical centre and to attend for assessment during a symptomatic deterioration

3. Severe asthma requiring GINA steps 4 or 5 treatment, confirmed after assessment by an asthma specialist.

4. Suitable for mepolizumab as per NICE/SMC Clinical Guidelines [new and existing participants].

\section{Exclusion:}

Participants who meet any of the following criteria will be excluded from study entry:

1. Acute exacerbation requiring oral corticosteroids in previous 4 weeks before the first visit

2. Other clinically significant medical disease or uncontrolled concomitant disease despite treatment that is likely, in the opinion of the investigator, to require a change in therapy or affect the ability to participate in the study 3. History of current alcohol, drug, or chemical abuse or past abuse that would impair or risk the participant's full participation in the study, in the opinion of the investigator

4. Treatment with an investigational agent within 30 days of Visit 1 (or five half-lives of the investigational agent, whichever is longer) 
5. Female participants who are pregnant or lactating (excluded as candidates for mepolizumab in clinic and prior to study).

\section{Patient reported outcomes questionnaires}

\section{ACQ5}

Asthma control was assessed by the five item asthma control questionnaire. ${ }^{3}$ An ACQ5 score of 0.75 reflects adequate asthma control, whereas a score of 1.5 or over signals inadequate asthma control. The MCID is a reduction in ACQ-5 score of 0.5 or greater. ${ }^{4}$

\section{Mini-AQLQ}

The mini-AQLQ consists of 15 questions scored on a scale of between 0 and 7 , a lower score reflects greater impairment with MCID being met when the mini-AQLQ improves by 0.5 or more ${ }^{.5}$

\section{St George's respiratory questionnaire}

The SGRQ assesses the impact of disease over the preceding 12 months, the higher the score the greater impact disease has on quality of life. The MCID is a score reduction of 4 units. ${ }^{6}$

\section{Study withdrawals}

In the period following initial study visit, 29 participants withdrew from the study; 15 had mepolizumab treatment stopped on the basis of non-response, four stopped due to side effects (headache and rash), four participants withdrew consent and 2 died (one of multi-organ failure secondary to sepsis, the other, presumed cardiac arrhythmia in the context of a known cardiomyopathy). Of the remaining four participants who withdrew, one patient wished to conceive, one relocated, one became too frail to attend unscheduled visits and the last had unrelated health concerns. 
Figure E1. MEX study visits A) For those initiating mepolizumab on entering the study B) For those entering the study already established on mepolizumab

A. New to mepolizumab on entering study:

Assessment at initiation of mepo

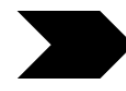

Assessment stable on mepolizumab*

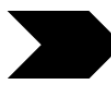

Unscheduled exacerbation visit

Assessment stable on mepolizumab*
Unscheduled exacerbation visit

*( $\geq$ week 12 on drug) 
Table E1. Participant demographics and comorbidities at initiation of mepolizumab therapy $(n=140)$ :

\begin{tabular}{|c|c|}
\hline \multicolumn{2}{|l|}{ Demographics at initiation of mepolizumab $(n=140)$} \\
\hline Male & $73(52 \cdot 1 \%)$ \\
\hline Caucasian & $134(95 \cdot 7 \%)$ \\
\hline Non-Caucasian & $6(4 \cdot 3 \%)$ \\
\hline Never Smoker & $94(67 \cdot 1 \%)$ \\
\hline $\begin{array}{l}\text { Ex-Smoker } \\
\text { Pack years }\end{array}$ & $\begin{array}{c}46(32 \cdot 9 \%) \\
14(8,26) \\
\end{array}$ \\
\hline Age at Diagnosis Asthma & $26 \cdot 8(19 \cdot 2)$ \\
\hline Age Commencing Mepolizumab & $54 \cdot 6(12 \cdot 0)$ \\
\hline BMI & $30 \cdot 4(8 \cdot 8)$ \\
\hline FENO (ppb) & $34 \cdot 0(22 \cdot 0,59 \cdot 0)$ \\
\hline $\mathrm{PEF}(\mathrm{L} / \mathrm{min})$ & $298 \cdot 4(205 \cdot 7)$ \\
\hline $\mathrm{FEV}_{1}(\%$ Predicted $)$ & $70 \cdot 4(20 \cdot 0)$ \\
\hline FVC (\% Predicted $)$ & $86 \cdot 3(16 \cdot 1)$ \\
\hline ACQ5 Total Score & $2 \cdot 8(1 \cdot 8,3 \cdot 6)$ \\
\hline Mini-AQLQ Total Score & $3 \cdot 8(2 \cdot 6,4 \cdot 9)$ \\
\hline SGRQ Total Score & $54 \cdot 9(39 \cdot 9,73 \cdot 0)$ \\
\hline Highest Blood Eosinophils last 12 months (cells/ $\mu \mathrm{L}$ ) & $650(430,890)$ \\
\hline \multicolumn{2}{|l|}{ Sputum at initiation of mepolizumab $(n=34 *)$} \\
\hline Sputum neutrophils $(\%)$ & $57 \cdot 5(20 \cdot 1,70 \cdot 3)$ \\
\hline Sputum Lymphocytes (\%) & $0 \cdot 0(0 \cdot 0,0 \cdot 7)$ \\
\hline Sputum Eosinophils (\%) & $2 \cdot 9(0 \cdot 5,12 \cdot 7)$ \\
\hline Sputum macrophages (\%) & $25 \cdot 4(16 \cdot 6,47 \cdot 4)$ \\
\hline \multicolumn{2}{|l|}{ Cohort comorbidities ( $n=140)$} \\
\hline Seasonal Allergic Rhinitis & $48(34.3 \%)$ \\
\hline Perennial Rhinitis & $62(44 \cdot 3 \%)$ \\
\hline Nasal Polyps & $60(42.9 \%)$ \\
\hline Allergic Dermatitis & $35(25.0 \%)$ \\
\hline Depression or Anxiety & $47(33.6 \%)$ \\
\hline Hypercholesterolaemia & $24(17 \cdot 1 \%)$ \\
\hline Myocardial Infarction & $5(3.6 \%)$ \\
\hline Osteoporosis or Osteopenia & $44(31.4 \%)$ \\
\hline Cataracts & $25(17.9 \%)$ \\
\hline Diabetes Mellitus & $21(15 \cdot 0 \%)$ \\
\hline Hypertension & $44(31 \cdot 4 \%)$ \\
\hline Obstructive Sleep Apnoea & $8(5 \cdot 7 \%)$ \\
\hline Peptic Ulcer & $7(5 \cdot 0 \%)$ \\
\hline Chronic Kidney Disease & $3(2 \cdot 1 \%)$ \\
\hline Glaucoma & $2(1.4 \%)$ \\
\hline Ischaemic Heart Disease & $6(4 \cdot 3 \%)$ \\
\hline Osteoarthritis & $27(19 \cdot 3 \%)$ \\
\hline Stroke & $4(2.9 \%)$ \\
\hline
\end{tabular}


Figure E2. Flow diagram of sputum differential cell counts used in each analysis.

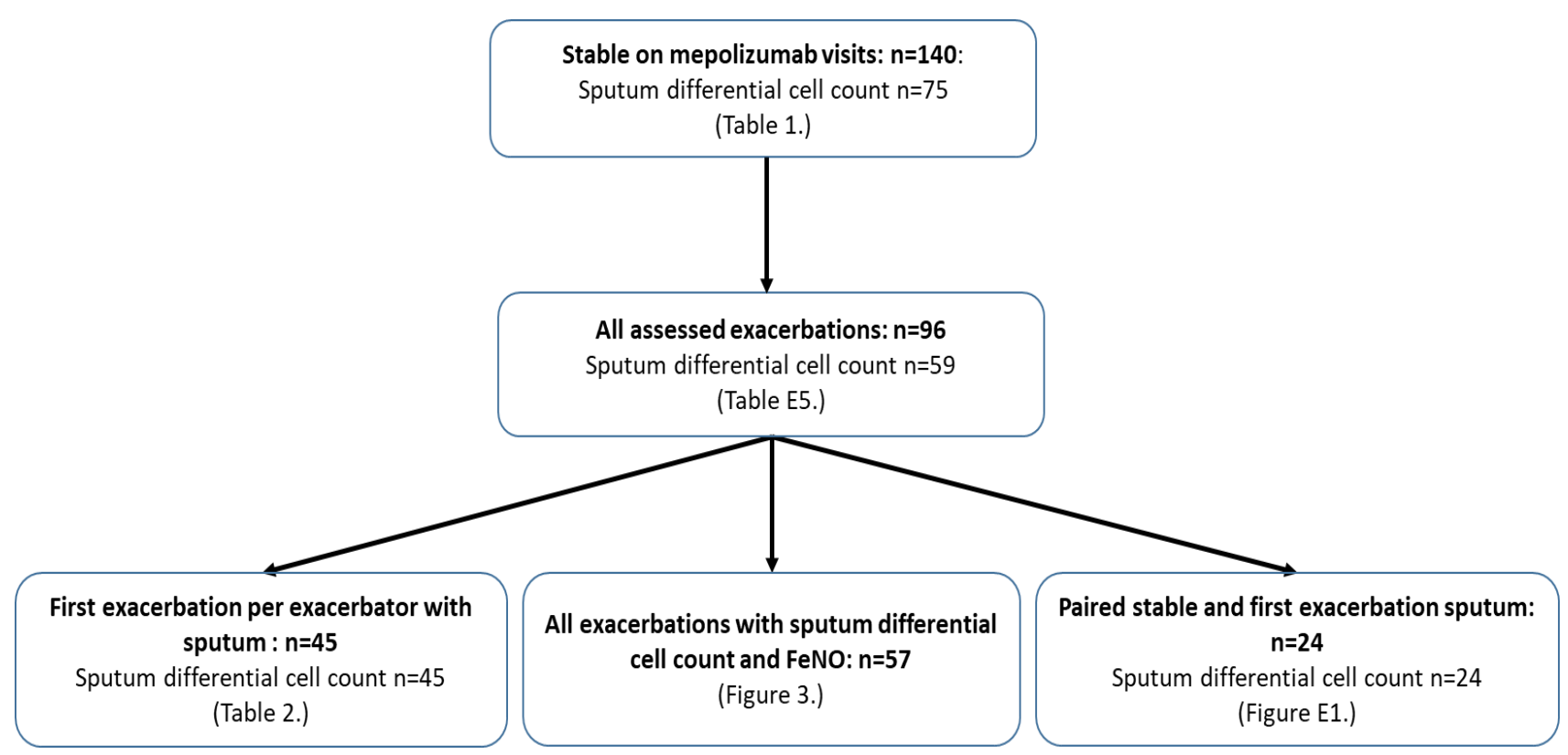

Each centre in this study has labs experienced in sputum processing, with each sputum count performed by two technicians to ensure accuracy at individual centres with standardized lab parameters for sputum acceptability being a squamous cell count of less than $30 \%$ and non-squamous cell viability of over $40 \%$. As part of our rigorous review of sputum analysis and consistency across centres, $50 \%$ of all sputum slides from this study were sent to the central lab for further quality control measures where the slides were recounted and viability and proportion of squamous cells assessed. Our quality control process at the central lab revealed that all samples had a squamous cell count of less than $30 \%$ and the mean non-squamous cell viability for all samples was $73.0 \%$ (SD 15.3\%). 
Table E2. Serious adverse events $(n=34)$ :

\begin{tabular}{|c|c|c|}
\hline SAE & $\begin{array}{l}\text { Hospital } \\
\text { admission }\end{array}$ & HDU/ITU \\
\hline Hospitalisation viral exacerbation of asthma. & YES & NO \\
\hline Hospitalisation with exacerbation asthma & YES & NO \\
\hline $\begin{array}{l}\text { Death: Found collapsed, unsuccessful resuscitation in community. Discussed with coroner, presumed cardiac arrhythmia } \\
\text { as known cardiomyopathy awaiting ICD. On MEPO since } 2013 \text { (clinical trial pre-NICE approvals). }\end{array}$ & NO & NO \\
\hline Non ST elevation MI: stents to eft anterior descending artery and left circumflex. & YES & NO \\
\hline Hospitalisation for urosepsis and acute kidney injury. & YES & NO \\
\hline Widespread maculopapular rash: Mepolizumab stopped. No hospitalisation. & NO & NO \\
\hline Idiopathic pancreatitis (known T2DM) & YES & NO \\
\hline Infective exacerbation of asthma & YES & NO \\
\hline Intra-abdominal sepsis due to gastroenteritis with secondary shock requiring ITU admission and vasopressor support. & YES & YES \\
\hline Death: admitted with sepsis of unknown origin and multi-organ failure. Decision for palliation and died 4-5 days later. & YES & NO \\
\hline Hospitalisation for asthma exacerbation & YES & NO \\
\hline Hospitalisation for asthma exacerbation & YES & NO \\
\hline Hospitalisation for pneumonia & YES & NO \\
\hline Hospitalisation for asthma exacerbation & YES & NO \\
\hline Fall and resolving pneumonia & YES & NO \\
\hline Hospitalisation for asthma exacerbation & YES & NO \\
\hline Hospitalisation for asthma exacerbation & YES & NO \\
\hline Hospitalisation for asthma exacerbation & YES & NO \\
\hline Hospitalisation for asthma exacerbation & YES & NO \\
\hline Exacerbation of asthma: withdrawn from study as over 3 exacerbations, not responsive to MEPO. & YES & NO \\
\hline Hospitalisation: Pulmonary embolism treated with Apixaban & YES & NO \\
\hline Hospitalisation: Influenza A & YES & YES \\
\hline Hospitalisation: Road traffic accident & YES & NO \\
\hline Hospitalisation with LLL Streptococcal pneumonia with secondary erythema multiforme & YES & NO \\
\hline Hospitalised with exacerbation Asthma & YES & NO \\
\hline Hospitalised with infective exacerbation Asthma & YES & $\mathrm{NO}$ \\
\hline Hospitalised with exacerbation Asthma & YES & NO \\
\hline $\begin{array}{l}\text { Cardiac event: witnessed p wave systole, emergency pace maker inserted. Possible clinical history of similar events } \\
\text { previously. }\end{array}$ & YES & NO \\
\hline Hospitalised for pneumonia with exacerbation of asthma & YES & NO \\
\hline Hospitalisation for abdominal pain, query pancreatitis. Previous history of pancreatitis. & YES & $\mathrm{NO}$ \\
\hline Hospitalisation for abdominal pain: cholecystitis. & YES & NO \\
\hline Loss of consciousness, query syncope. Normal ECG, EF 45-55\%, moderate aortic stenosis. For cardiology follow-up. & YES & NO \\
\hline Hospitalisation for asthma exacerbation & YES & NO \\
\hline Hospitalisation exacerbation asthma. & YES & NO \\
\hline
\end{tabular}

\section{Serious adverse events:}

A total of 34 serious adverse events reported of which none were study related; 32 of the 34 (94\%) adverse events included hospitalisation of which 3 (9\%) included an HDU/ITU admission. Two deaths were reported, one a presumed cardiac arrhythmia in a patient with known cardiomyopathy awaiting an ICD, the other sepsis with multiorgan failure and decision to palliate.

Approximately half (17/32) of all reported hospitalisations due to asthma exacerbations. Of the remaining, there were $4(12 \%)$ pneumonias, 3 (9\%)cardiac events including an MI and 2 arrhythmias, 3 (9\%) intra-abdominal events and $5(16 \%)$ 'other' events include investigation for syncope, a road traffic accident, pulmonary embolism, influenza A and a fall. 
Table E3. Comparison of participants with one or more exacerbations (missed or assessed) versus participants who remained exacerbation free for the duration of the study.

\begin{tabular}{|c|c|c|c|}
\hline & No Exacerbations & $\geq 1$ Exacerbation & $\mathbf{p}$ \\
\hline Number of Patients $N=140$ & $53(38 \%)$ & $87(62 \%)$ & \\
\hline Time in study (Years) & $0 \cdot 8(0 \cdot 4)$ & $0.9(0 \cdot 3)$ & $0 \cdot 01$ \\
\hline $\begin{array}{c}\text { Exacerbation count } \\
0 \\
1 \\
2 \\
3 \\
4 \\
5\end{array}$ & $\begin{array}{c}53(100 \cdot 0 \%) \\
0(0 \cdot 0 \%) \\
0(0 \cdot 0 \%) \\
0(0 \cdot 0 \%) \\
0(0 \cdot 0 \%) \\
0(0 \cdot 0 \%)\end{array}$ & $\begin{array}{c}0(0 \cdot 0 \%) \\
41(47 \cdot 1 \%) \\
21(24 \cdot 1 \%) \\
14(16 \cdot 1 \%) \\
8(9 \cdot 2 \%) \\
3(3 \cdot 4 \%)\end{array}$ & $<0 \cdot 001$ \\
\hline Maintenance Prednisolone on study entry & $41(77.4 \%)$ & $62(71 \cdot 3 \%)$ & 0.43 \\
\hline $\begin{array}{l}\text { Maintenance Prednisolone dose (mg) on study entry } \\
(\mathrm{n}=103)\end{array}$ & $10 \cdot 0(10 \cdot 0,10 \cdot 0)$ & $10 \cdot 0(6 \cdot 3,15 \cdot 0)$ & 0.92 \\
\hline Maintenance Prednisolone on study exit & $35(68 \cdot 6 \%)$ & $44(51 \cdot 8 \%)$ & $0 \cdot 054$ \\
\hline Maintenance Prednisolone dose (mg) on study exit $(n=79)$ & $5 \cdot 0(4 \cdot 0,5 \cdot 0)$ & $5 \cdot 0(4 \cdot 5,10 \cdot 0)$ & $0 \cdot 32$ \\
\hline HPA Axis Suppression $(n=93)$ & $17(45 \cdot 9 \%)$ & $18(32 \cdot 1 \%)$ & $0 \cdot 18$ \\
\hline Pre-initiation of mepolizumab $\mathrm{N}=140$ & No Exacerbations $(n=53)$ & $>1$ Exacerbation $(n=87)$ & p \\
\hline Male & $30(56 \cdot 6 \%)$ & $43(49.4 \%)$ & $0 \cdot 41$ \\
\hline Age Commencing Mepolizumab & $55 \cdot 5(11 \cdot 5)$ & $54 \cdot 0(12 \cdot 3)$ & $0 \cdot 50$ \\
\hline Occupational Worsening of Asthma & $0(0 \cdot 0 \%)$ & $6(6 \cdot 9 \%)$ & $0 \cdot 051$ \\
\hline $\begin{array}{l}\text { Smoking Status } \\
\text { Never Smoker } \\
\text { Ex-Smoker }\end{array}$ & $\begin{array}{l}37(69 \cdot 8 \%) \\
16(30 \cdot 2 \%)\end{array}$ & $\begin{array}{l}57(65 \cdot 5 \%) \\
30(34 \cdot 5 \%)\end{array}$ & $0 \cdot 60$ \\
\hline Age at Diagnosis Asthma & $27 \cdot 4(19 \cdot 8)$ & $26 \cdot 4(18 \cdot 9)$ & 0.77 \\
\hline Seasonal Allergic Rhinitis & $14(26 \cdot 4 \%)$ & $34(39 \cdot 1 \%)$ & $0 \cdot 13$ \\
\hline Perennial Rhinitis & $29(54.7 \%)$ & $33(37.9 \%)$ & $0 \cdot 052$ \\
\hline Nasal Polyps & $29(54 \cdot 7 \%)$ & $31(35 \cdot 6 \%)$ & $0 \cdot 027$ \\
\hline Allergic Dermatitis & $11(20 \cdot 8 \%)$ & $24(27.6 \%)$ & $0 \cdot 37$ \\
\hline Number of Exacerbations Prior 12 Months & $3 \cdot 0(2 \cdot 0,5 \cdot 0)$ & $5 \cdot 0(3 \cdot 0,7 \cdot 0)$ & $0 \cdot 002$ \\
\hline Number of ED Visits Prior 12 Months & $0 \cdot 0(0 \cdot 0,0 \cdot 0)$ & $0 \cdot 0(0 \cdot 0,1 \cdot 0)$ & $0 \cdot 01$ \\
\hline Number Hospital Admissions Prior 12 Months & $0 \cdot 0(0 \cdot 0,0 \cdot 0)$ & $0 \cdot 0(0 \cdot 0,1 \cdot 0)$ & 0.067 \\
\hline Number ITU/HDU Admissions Ever & $0 \cdot 0(0 \cdot 0,0 \cdot 0)$ & $0 \cdot 0(0 \cdot 0,0 \cdot 0)$ & 0.59 \\
\hline $\begin{array}{l}\text { Established on mepolizumab and clinically stable } \\
\mathrm{N}=138\end{array}$ & No Exacerbations $(n=52)$ & $>1$ Exacerbation $(n=86)$ & $\mathbf{p}$ \\
\hline BMI & $27 \cdot 2(11 \cdot 6)$ & $28 \cdot 4(11 \cdot 2)$ & $0 \cdot 64$ \\
\hline FENO (ppb) & $34 \cdot 0(20 \cdot 0,64 \cdot 0)$ & $32 \cdot 0(18 \cdot 0,69 \cdot 0)$ & $0 \cdot 91$ \\
\hline $\mathrm{FEV}_{1}(\%$ Predicted $)$ & $72 \cdot 1(20 \cdot 1)$ & $71 \cdot 6(21 \cdot 5)$ & $0 \cdot 91$ \\
\hline $\mathrm{FEV}_{1} / \mathrm{FVC}$ & $66 \cdot 0(10 \cdot 9)$ & $64 \cdot 0(11 \cdot 7)$ & $0 \cdot 31$ \\
\hline ACQ5 Total Score & $1 \cdot 4(0 \cdot 6,2 \cdot 6)$ & $2 \cdot 2(1 \cdot 2,3 \cdot 2)$ & $0 \cdot 002$ \\
\hline Mini-AQLQ Total Score & $(5 \cdot 4(4 \cdot 3,6 \cdot 6)$ & $4 \cdot 1(3 \cdot 0,5 \cdot 9)$ & $0 \cdot 001$ \\
\hline SGRQ Total Score & $39 \cdot 5(12 \cdot 8,57 \cdot 2)$ & $49 \cdot 9(26 \cdot 7,67 \cdot 0)$ & $0 \cdot 02$ \\
\hline Blood Eosinophils (cells $/ \mu \mathrm{L})$ & $70(40,110)$ & $50(30,80)$ & $0 \cdot 073$ \\
\hline $\begin{array}{l}\text { Fall in PBE from highest PBE in the } 12 \text { months prior to } \\
\text { mepolizumab to PBE when stable on mepolizumab }\end{array}$ & $580(360,860)$ & $590(400,820)$ & 0.98 \\
\hline $\mathrm{CRP}(\mathrm{mg} / \mathrm{L}) \mathrm{N}=80$ & $4 \cdot 9(2 \cdot 0,6 \cdot 0)$ & $3 \cdot 5(1 \cdot 5,6 \cdot 0)$ & 0.46 \\
\hline Sputum Neutrophils $\%$ of cells N=75 & $43 \cdot 8(22 \cdot 1,71 \cdot 5)$ & $47 \cdot 0(28 \cdot 1,65 \cdot 5)$ & $0 \cdot 64$ \\
\hline Sputum Eosinophils \% of cells $\mathrm{N}=75$ & $1 \cdot 3(0 \cdot 2,5 \cdot 8)$ & $1 \cdot 2(0 \cdot 2,5 \cdot 1)$ & $0 \cdot 86$ \\
\hline \multicolumn{4}{|l|}{ Sputum PCR $(\mathrm{N}=69)$ : } \\
\hline Virus & $5(16 \cdot 7 \%)$ & $3(7.7 \%)$ & $0 \cdot 25$ \\
\hline Total 16s Copies/ml & $7 \cdot 5 \times 10^{\wedge} 8\left(1 \cdot 6 \times 10^{\wedge} 8,2 \cdot 2 \times 10^{\wedge} 9\right)$ & $\begin{array}{c}9 \cdot 6 \times 10^{\wedge} 8 \\
\left(2 \cdot 8 \times 10^{\wedge} 8,3 \cdot 0 \times 10^{\wedge} 9\right)\end{array}$ & $0 \cdot 39$ \\
\hline Any qPCR Bacteria Positive above threshold of detection & $15(50 \cdot 0 \%)$ & $24(61 \cdot 5 \%)$ & $0 \cdot 34$ \\
\hline Any Bacteria Positive $\left(>10^{\wedge} 6\right)$ & $12(40 \cdot 0 \%)$ & $13(33 \cdot 3 \%)$ & 0.57 \\
\hline $\mathrm{MC}\left(\geq 10^{\wedge} 6\right.$ genome copies $\left./ \mathrm{ml}\right)$ & $2(6 \cdot 7 \%)$ & $2(5 \cdot 1 \%)$ & 0.79 \\
\hline $\mathrm{HI}\left(\geq 10^{\wedge} 6\right.$ genome copies $\left./ \mathrm{ml}\right)$ & $4(13 \cdot 3 \%)$ & $6(15 \cdot 4 \%)$ & $0 \cdot 81$ \\
\hline $\mathrm{SP}\left(\geq 10^{\wedge} 6\right.$ genome copies $\left./ \mathrm{ml}\right)$ & $7(23 \cdot 3 \%)$ & $6(15 \cdot 4 \%)$ & $0 \cdot 40$ \\
\hline Any Virus or Bacteria $\left(>10^{\wedge} 6\right)$ & $16(53 \cdot 3 \%)$ & $14(35.9 \%)$ & $0 \cdot 15$ \\
\hline \multicolumn{4}{|c|}{$\begin{array}{l}\text { Data are presented as mean (SD), median (IQR) and count (\%). Independent sample T-tests, Mann-Whitney U tests and chi-square tests were used } \\
\text { to compare groups. *PBE: peripheral blood eosinophils. } \\
\text { Specific bacteria: PCR for specific bacteria includes Moraxella catarralis (MC), Haemophilus influenzae (HI), Streptococcus pneumonia (SP). } \\
\text { Virus: PCR for Influenza A, Influenza B, Respiratory Syncytial virus A, Respiratory Syncytial virus B, Rhinovirus, Metapneumovirus, Adenoviurs, } \\
\text { Parainfluenza 1, Parainfluenza 2, Parainfluenza 3, Parainfluenza } 4 \text { and Coronavirus. }\end{array}$} \\
\hline
\end{tabular}


Table E4. Details of missed exacerbations

\begin{tabular}{|c|c|c|}
\hline \multicolumn{3}{|l|}{ Symptoms of missed exacerbation } \\
\hline New or Increased Breathlessness & $\mathrm{N}=76$ & $70(92 \cdot 1 \%)$ \\
\hline Cough & $\mathrm{N}=76$ & $64(84 \cdot 2 \%)$ \\
\hline Wheeze & $\mathrm{N}=76$ & $63(82.9 \%)$ \\
\hline Change in Sputum Volume & $\mathrm{N}=76$ & $57(75 \cdot 0 \%)$ \\
\hline Increased Nocturnal Wakening & $\mathrm{N}=76$ & $55(72.4 \%)$ \\
\hline Increased Sputum Purulence & $\mathrm{N}=76$ & $47(61.8 \%)$ \\
\hline Preceding Coryzal Symptoms & $\mathrm{N}=76$ & $30(39 \cdot 5 \%)$ \\
\hline Fevers & $\mathrm{N}=76$ & $21(27.6 \%)$ \\
\hline Haemoptysis & $\mathrm{N}=76$ & $8(10 \cdot 5 \%)$ \\
\hline \multicolumn{3}{|l|}{ Action at exacerbation } \\
\hline General Practitioner & $\mathrm{N}=76$ & $35(46 \cdot 1 \%)$ \\
\hline Asthma Action Plan & $\mathrm{N}=76$ & $32(42 \cdot 1 \%)$ \\
\hline Hospital Asthma Nurse & $\mathrm{N}=76$ & $7(9 \cdot 2 \%)$ \\
\hline ED Attendance & $\mathrm{N}=76$ & $6(7 \cdot 9 \%)$ \\
\hline Primary Care Asthma Nurse & $\mathrm{N}=76$ & $1(1 \cdot 3 \%)$ \\
\hline Hospital Admission & $\mathrm{N}=76$ & $12(15 \cdot 8 \%)$ \\
\hline ITU/HDU Admission & $\mathrm{N}=65$ & $1(1.5 \%)$ \\
\hline \multicolumn{3}{|l|}{ Treatment of missed exacerbation } \\
\hline Commenced/increased Oral Steroids & $\mathrm{N}=76$ & $69(90 \cdot 8 \%)$ \\
\hline Commenced Antibiotics & $\mathrm{N}=76$ & $43(56 \cdot 6 \%)$ \\
\hline Increased ICS inhaler & $\mathrm{N}=76$ & $6(7 \cdot 9 \%)$ \\
\hline Increased Nebulisers & $\mathrm{N}=76$ & $27(35 \cdot 5 \%)$ \\
\hline Increase in Medication has helped & $\mathrm{N}=76$ & $53(69 \cdot 7 \%)$ \\
\hline
\end{tabular}


Table E5. All assessed exacerbations on mepolizumab prior to any treatment $(n=96)$.

\begin{tabular}{|c|c|}
\hline \multicolumn{2}{|l|}{ Symptoms at exacerbation $(n=96)$} \\
\hline Time from mepolizumab initiation to exacerbation (years) & $0 \cdot 8[0 \cdot 5,1 \cdot 2]$ \\
\hline Days since last mepolizumab administration & $13(6,24)$ \\
\hline New or Increased Breathlessness & $93(96 \cdot 9 \%)$ \\
\hline Breathless at Rest & $48(52 \cdot 2 \%)$ \\
\hline Breathless when Walking & $36(39 \cdot 1 \%)$ \\
\hline Breathless on moderate Exertion (Just Below Usual Level) & $8(8.7 \%)$ \\
\hline Increased Nocturnal Wakening & $82(85 \cdot 4 \%)$ \\
\hline Cough & $82(85 \cdot 4 \%)$ \\
\hline Decrease in Exercise Tolerance & $78(83 \cdot 0 \%)$ \\
\hline Wheeze & $78(81 \cdot 3 \%)$ \\
\hline Change in Sputum Volume & $69(71.9 \%)$ \\
\hline Increased Sputum Purulence & $48(50 \cdot 0 \%)$ \\
\hline Preceding Coryzal Symptoms & $47(49 \cdot 0 \%)$ \\
\hline Fevers & $33(34 \cdot 4 \%)$ \\
\hline Haemoptysis & $6(6 \cdot 3 \%)$ \\
\hline \multicolumn{2}{|l|}{ Unscheduled Visit: Clinical Diagnosis (n=92) } \\
\hline Non-Infective Exacerbation Of Asthma & $41(44 \cdot 6 \%)$ \\
\hline Viral Upper Respiratory Tract Infection & $24(26 \cdot 1 \%)$ \\
\hline Viral Lower Respiratory Tract Infection & $12(13 \cdot 0 \%)$ \\
\hline Bacterial Upper Respiratory Tract Infection & $5(5 \cdot 4 \%)$ \\
\hline Bacterial Lower Respiratory Tract Infection & $3(3 \cdot 3 \%)$ \\
\hline Pneumonia & $1(1 \cdot 1 \%)$ \\
\hline Sinusitis & $2(2 \cdot 2 \%)$ \\
\hline Vocal Cord Dysfunction & $1(1 \cdot 1 \%)$ \\
\hline Stress & $1(1 \cdot 1 \%)$ \\
\hline Secondary To Prednisolone Reduction & $1(1 \cdot 1 \%)$ \\
\hline Other & $1(1 \cdot 1 \%)$ \\
\hline \multicolumn{2}{|l|}{ Unscheduled visit : Treatment $(n=96)$} \\
\hline High Dose OCS Initiated & $61(63 \cdot 5 \%)$ \\
\hline Antibiotics Initiated & $26(27 \cdot 1 \%)$ \\
\hline Nebulisers Initiated & $10(10 \cdot 4 \%)$ \\
\hline Hospital Admission & $5(5 \cdot 2 \%)$ \\
\hline \multicolumn{2}{|l|}{ Unscheduled visit: Review Phone Call (n=92) } \\
\hline Improved & $63(68 \cdot 5 \%)$ \\
\hline Much The Same & $26(28 \cdot 3 \%)$ \\
\hline Worsened & $3(3 \cdot 3 \%)$ \\
\hline Recovery Longer Than Pre-Mepolizumab & $13(13 \cdot 5 \%)$ \\
\hline Initiated OCS after assessed visit & $13(13 \cdot 5 \%)$ \\
\hline Initiated antibiotics after assessed visit & $3(3 \cdot 1 \%)$ \\
\hline \multicolumn{2}{|l|}{ Physiological and biochemical measurements at exacerbation } \\
\hline $\begin{array}{l}\text { Respiratory Rate }(\mathrm{Bpm}) \\
\quad \text { Respiratory Rate } \geq 20 \mathrm{Bpm}\end{array}$ & $\begin{array}{c}18 \cdot 0(16 \cdot 0,22 \cdot 0) \\
42(44 \cdot 2 \%)\end{array}$ \\
\hline $\begin{array}{l}\text { Sp02 Room Air } \\
\text { Sp02 } \leq 94 \% \text { Room Air }\end{array}$ & $\begin{array}{c}96 \cdot 0(95 \cdot 0,97 \cdot 0) \\
16(16 \cdot 7 \%)\end{array}$ \\
\hline $\begin{array}{l}\text { Heart Rate }(\mathrm{Bpm}) \\
\text { Heart Rate } \geq 100 \mathrm{Bpm}\end{array}$ & $\begin{array}{l}86 \cdot 3(14 \cdot 7) \\
17(17 \cdot 7 \%)\end{array}$ \\
\hline Temperature $\left({ }^{\circ} \mathrm{C}\right)$ & $36 \cdot 2(3 \cdot 4)$ \\
\hline Temperature $\geq 37.5^{\circ} \mathrm{C}$ & $5(5 \cdot 2 \%)$ \\
\hline Temperature $\leq 35^{\circ} \mathrm{C}$ & $0(0 \%)$ \\
\hline Systolic Blood Pressure (mmHg) & $132 \cdot 6(15 \cdot 7)$ \\
\hline FENO (ppb) & $47 \cdot 0(22 \cdot 0,81 \cdot 0)$ \\
\hline$<20$ & $22(24 \cdot 2 \%)$ \\
\hline$\geq 50$ & $43(47 \cdot 3 \%)$ \\
\hline $\mathrm{PEF}(\mathrm{L} / \mathrm{min})$ & $307 \cdot 6(115 \cdot 9)$ \\
\hline $\mathrm{FEV}_{1}(\%$ Predicted $)$ & $61 \cdot 3(20 \cdot 0)$ \\
\hline FVC (\% Predicted) & $84 \cdot 0(68 \cdot 2)$ \\
\hline $\mathrm{FEV}_{1} / \mathrm{FVC}(\%)$ & $63 \cdot 3(12 \cdot 9)$ \\
\hline$<70 \%$ & $59(63.4 \%)$ \\
\hline ACQ-5 Total Score & $3 \cdot 6(2 \cdot 6,4 \cdot 1)$ \\
\hline Blood Neutrophils $\left(10^{\wedge} 9 / \mathrm{L}\right)$ & $5 \cdot 5(4 \cdot 2,7 \cdot 5)$ \\
\hline Blood Eosinophils (cells $/ \mu \mathrm{L})$ & $50(20,90)$ \\
\hline$\geq 100$ cells $/ \mu \mathrm{L}$ & $21(22 \cdot 6 \%)$ \\
\hline $\mathrm{CRP}(\mathrm{mg} / \mathrm{L})$ & $5 \cdot 0(2 \cdot 0,14 \cdot 0)$ \\
\hline \multicolumn{2}{|l|}{ Sputum at exacerbation $(\mathrm{N}=59)$} \\
\hline Sputum Neutrophils \% of cells & $59 \cdot 5(33 \cdot 4,91 \cdot 9)$ \\
\hline$\geq 65 \%$ & $28(47.5 \%)$ \\
\hline Sputum Eosinophils \% of cells & $1 \cdot 3(0 \cdot 3,10 \cdot 4)$ \\
\hline$\geq 2 \%$ & $28(47 \cdot 5 \%)$ \\
\hline Sputum neutrophils $\geq 65 \%$ and eosinophils $\geq 2 \%$ & $3(5 \cdot 1 \%)$ \\
\hline Sputum Lymphocyte \% of cells & $0 \cdot 2(0 \cdot 0,1 \cdot 5)$ \\
\hline Sputum Macrophages\% of cells & $16 \cdot 6(5 \cdot 4,42 \cdot 7)$ \\
\hline
\end{tabular}


Table E6. Participant characteristics when stable on mepolizumab compared to first exacerbation per exacebator $(n=69)$.

\begin{tabular}{|c|c|c|c|c|}
\hline & $\begin{array}{c}\text { Number } \\
\text { paired } \\
\text { data }\end{array}$ & $\begin{array}{c}\text { Stable on } \\
\text { mepolizumab }\end{array}$ & First Exacerbation & $\mathbf{p}$ \\
\hline Time mepo Initiation to Exacerbation (years) & $\mathrm{N}=69$ & & $0.7(0 \cdot 4,1 \cdot 0)$ & \\
\hline Temperature $\left({ }^{\circ} \mathrm{C}\right)$ & $\mathrm{N}=65$ & $36 \cdot 5(0 \cdot 5)$ & $36 \cdot 1(4 \cdot 1)$ & 0.45 \\
\hline Heart Rate (BPM) & $\mathrm{N}=66$ & $82 \cdot 7(13 \cdot 7)$ & $86 \cdot 9(15 \cdot 7)$ & $0 \cdot 018$ \\
\hline Respiratory Rate (BPM) & $\mathrm{N}=63$ & $16 \cdot 0(14 \cdot 0,16 \cdot 0)$ & $18 \cdot 0(16 \cdot 0,22 \cdot 0)$ & $<0 \cdot 001$ \\
\hline Sp02 Room Air & $\mathrm{N}=66$ & $96 \cdot 5(95 \cdot 0,98 \cdot 0)$ & $96 \cdot 0(95 \cdot 0,97 \cdot 0)$ & $0 \cdot 078$ \\
\hline $\mathrm{PEF}(\mathrm{L} / \mathrm{min})$ & $\mathrm{N}=62$ & $396 \cdot 2(141 \cdot 4)$ & $312 \cdot 8(120 \cdot 8)$ & $<0 \cdot 001$ \\
\hline $\mathrm{FEV}_{1}(\%$ Predicted $)$ & $\mathrm{N}=64$ & $73 \cdot 4(21 \cdot 2)$ & $61 \cdot 4(20 \cdot 0)$ & $<0 \cdot 001$ \\
\hline $\mathrm{FEV}_{1} / \mathrm{FVC}$ & $\mathrm{N}=64$ & $65 \cdot 7(10 \cdot 6)$ & $63 \cdot 8(12 \cdot 0)$ & $0 \cdot 066$ \\
\hline ACQ-5 Total Score & $\mathrm{N}=66$ & $2 \cdot 4(1 \cdot 2,3 \cdot 2)$ & $3 \cdot 6(2 \cdot 6,4 \cdot 0)$ & $<0 \cdot 001$ \\
\hline Total WCC $\left(10^{\wedge} 9 / \mathrm{L}\right)$ & $\mathrm{N}=64$ & $8 \cdot 3(7 \cdot 0,10 \cdot 0)$ & $8 \cdot 4(6 \cdot 4,10 \cdot 5)$ & $0 \cdot 52$ \\
\hline Blood Neutrophils (10^9/L) & $\mathrm{N}=64$ & $5 \cdot 5(4 \cdot 4,7 \cdot 5)$ & $5 \cdot 6(4 \cdot 2,7 \cdot 7)$ & 0.41 \\
\hline Blood Lymphocytes (10^9/L) & $\mathrm{N}=64$ & $1 \cdot 7(1 \cdot 3,2 \cdot 4)$ & $1 \cdot 7(1 \cdot 2,2 \cdot 2)$ & $0 \cdot 26$ \\
\hline Blood Eosinophils (cells $/ \mu \mathrm{L})$ & $\mathrm{N}=64$ & $50(30,70)$ & $50(20,90)$ & 0.96 \\
\hline $\mathrm{CRP}(\mathrm{mg} / \mathrm{L})$ & $\mathrm{N}=41$ & $3 \cdot 5(1 \cdot 5,6 \cdot 0)$ & $5 \cdot 0(1 \cdot 5,8 \cdot 0)$ & $0 \cdot 028$ \\
\hline
\end{tabular}


Table E7. Baseline characteristics at initiation of mepolizumab: sputum eosinophil high and sputum eosinophil low first exacerbation per participant with sputum.

\begin{tabular}{|c|c|c|c|}
\hline & $\begin{array}{c}\text { Sputum eosinophils } \\
<2 \%(n=24)\end{array}$ & $\begin{array}{l}\text { Sputum eosinophils } \\
\geq 2 \%(n=21)\end{array}$ & $\mathbf{p}$ \\
\hline Male & $12(50 \cdot 0 \%)$ & $11(52 \cdot 4 \%)$ & 0.87 \\
\hline Age Commencing Mepolizumab & $56 \cdot 3(9 \cdot 2)$ & $54 \cdot 0(10 \cdot 5)$ & 0.44 \\
\hline Age at Diagnosis Asthma & $28 \cdot 2(20 \cdot 0)$ & $25 \cdot 8(21 \cdot 6)$ & 0.70 \\
\hline Seasonal Allergic Rhinitis & $11(45 \cdot 8 \%)$ & $7(33 \cdot 3 \%)$ & 0.39 \\
\hline Perennial Rhinitis & $9(37.5 \%)$ & $4(19 \cdot 0 \%)$ & $0 \cdot 17$ \\
\hline Nasal Polyps & $6(25 \cdot 0 \%)$ & $7(33 \cdot 3 \%)$ & 0.54 \\
\hline Allergic Dermatitis & $7(29 \cdot 2 \%)$ & $5(23 \cdot 8 \%)$ & 0.69 \\
\hline Number of Exacerbations Prior 12 Months & $6 \cdot 0(3 \cdot 0,7 \cdot 0)$ & $5 \cdot 0(4 \cdot 0,9 \cdot 0)$ & 0.45 \\
\hline Number of ED Visits Prior 12 Months & $0 \cdot 0(0 \cdot 0,0 \cdot 0)$ & $0 \cdot 0(0 \cdot 0,3 \cdot 0)$ & 0.06 \\
\hline Number Hospital Admissions Prior 12 Months & $0 \cdot 0(0 \cdot 0,1 \cdot 0)$ & $0 \cdot 0(0 \cdot 0,1 \cdot 0)$ & 0.62 \\
\hline Number ITU/HDU Admissions Ever & $0 \cdot 0(0 \cdot 0,0 \cdot 0)$ & $0 \cdot 0(0 \cdot 0,1 \cdot 0)$ & 0.09 \\
\hline BMI & $33 \cdot 0(8 \cdot 3)$ & $28 \cdot 5(11 \cdot 1)$ & $0 \cdot 12$ \\
\hline FENO (ppb) & $33 \cdot 0(20 \cdot 0,42 \cdot 0)$ & $54 \cdot 0(22 \cdot 0,76 \cdot 0)$ & $0 \cdot 17$ \\
\hline $\mathrm{FEV}_{1}(\%$ Predicted $)$ & $74 \cdot 1(18 \cdot 7)$ & $67 \cdot 2(16 \cdot 4)$ & $0 \cdot 20$ \\
\hline ACQ5 Total Score & $2 \cdot 7(2 \cdot 3,3 \cdot 6)$ & $3 \cdot 0(2 \cdot 0,4 \cdot 0)$ & 0.72 \\
\hline Mini-AQLQ Total Score & $3 \cdot 7(2 \cdot 9,4 \cdot 7)$ & $3 \cdot 5(1 \cdot 7,5 \cdot 2)$ & 0.74 \\
\hline SGRQ Total Score & $45 \cdot 3(37 \cdot 2,71 \cdot 8)$ & $54 \cdot 2(45 \cdot 9,83 \cdot 8)$ & $0 \cdot 26$ \\
\hline Highest Eosinophils Year Before Mepo (cells/ $\mu \mathrm{L})$ & $630(360,890)$ & $710(470,890)$ & $0 \cdot 28$ \\
\hline
\end{tabular}


Table E8. Participant characteristics when clinically stable on mepolizumab ( $\geq \mathbf{3}$ months treatment) for those with sputum eosinophils $<2 \%$ and those with sputum eosinophils $\geq 2 \%$ at first exacerbation per participant with sputum.

\begin{tabular}{|c|c|c|c|c|}
\hline & Eos $<2 \%(n=24)$ & $\operatorname{Eos} \geq 2 \%(n=21)$ & Effect Size (95\% CI) & $\mathbf{p}$ \\
\hline Maintenance prednisolone stable on mepolizumab ${ }^{\mathrm{a}}$ & $18(75 \cdot 0 \%)$ & $16(76 \cdot 2 \%)$ & $1 \cdot 1(0 \cdot 2,5 \cdot 3)$ & $0 \cdot 93$ \\
\hline Prednisolone Dose $(\mathrm{mg})$ stable on mepolizumab $(\mathrm{n}=34)^{\mathrm{b}}$ & $8 \cdot 8(5 \cdot 0,10 \cdot 0)$ & $10 \cdot 0(7 \cdot 5,20 \cdot 0)$ & $1 \cdot 3(-2 \cdot 5,12 \cdot 5)$ & $0 \cdot 34$ \\
\hline FENO $(\mathrm{ppb})^{\mathrm{b}}$ & $22 \cdot 0(15 \cdot 0,37 \cdot 0)$ & $68 \cdot 0(29 \cdot 5,116 \cdot 0)$ & $46 \cdot 0(11 \cdot 0,88 \cdot 0)$ & $<0 \cdot 001$ \\
\hline $\mathrm{FEV}_{1}(\% \text { Predicted })^{\mathrm{b}}$ & $79 \cdot 3(23 \cdot 4)$ & $70 \cdot 4(15 \cdot 1)$ & $-8 \cdot 9(-20 \cdot 9,3 \cdot 2)$ & $0 \cdot 16$ \\
\hline Mini-AQLQ & $4 \cdot 6(3 \cdot 5 \cdot 6 \cdot 5)$ & $4 \cdot 6(3 \cdot 1,6 \cdot 0)$ & $-0 \cdot 05(-2 \cdot 1,1 \cdot 2)$ & $0 \cdot 52$ \\
\hline SGRQ & $47 \cdot 6(18 \cdot 6,66 \cdot 3)$ & $46 \cdot 3(26 \cdot 0,70 \cdot 3)$ & $-1 \cdot 3(-22 \cdot 1,33 \cdot 8)$ & $0 \cdot 80$ \\
\hline Blood Eosinophils (cells $/ \mu \mathrm{L})^{\mathrm{b}}$ & $40(30,70)$ & $50(20,110)$ & $5(-20,50)$ & $0 \cdot 58$ \\
\hline $\mathrm{CRP}(\mathrm{mg} / \mathrm{L})^{\mathrm{b}}$ & $4 \cdot 9(2 \cdot 9,7 \cdot 0)$ & $2 \cdot 2(1 \cdot 2,6 \cdot 0)$ & $-2 \cdot 7(-4 \cdot 3,1 \cdot 5)$ & $0 \cdot 18$ \\
\hline Total cell count $\times 10^{\wedge} 6 / g(n=24)^{b}$ & $2 \cdot 3(0 \cdot 5,6 \cdot 8)$ & $1 \cdot 7(1 \cdot 0,3 \cdot 0)$ & $-0 \cdot 6(-5 \cdot 1,1 \cdot 6)$ & $0 \cdot 71$ \\
\hline Sputum Neutrophils $\%$ of cells $(n=24)^{b}$ & $59 \cdot 5(40 \cdot 3,80 \cdot 5)$ & $30 \cdot 7(29 \cdot 4,40 \cdot 3)$ & $-28 \cdot 8(-42 \cdot 5,-3 \cdot 0)$ & $0 \cdot 06$ \\
\hline Sputum Lymphocyte $\%$ of cells $(n=24)^{b}$ & $0 \cdot 0(0 \cdot 0,0 \cdot 8)$ & $0 \cdot 0(0 \cdot 0,0 \cdot 3)$ & $0 \cdot 0(-0 \cdot 6,0 \cdot 4)$ & $0 \cdot 59$ \\
\hline Sputum Eosinophils $\%$ of cells $(n=24)^{b}$ & $0 \cdot 8(0 \cdot 0,2 \cdot 5)$ & $3 \cdot 4(1 \cdot 3,31 \cdot 8)$ & $2 \cdot 7(0 \cdot 4,31 \cdot 5)$ & $0 \cdot 01$ \\
\hline Sputum Macrophages $\%$ of cells $(n=24)^{b}$ & $32 \cdot 5(17 \cdot 3,41 \cdot 0)$ & $34 \cdot 9(15 \cdot 7,64 \cdot 7)$ & $2 \cdot 4(-18 \cdot 4,32 \cdot 7)$ & $0 \cdot 82$ \\
\hline Virus positive on PCR $(n=22)$ & $0(0 \cdot 0 \%)$ & $1(9 \cdot 1 \%)$ & & $0 \cdot 31$ \\
\hline Total 16s Copies/ml $(\mathrm{n}=22)$ & $\begin{array}{c}9 \cdot 8 \times 10^{\wedge} 8 \\
\left(2 \cdot 1 \times 10^{\wedge} 8,3 \cdot 2 \times 10^{\wedge} 9\right) \\
\end{array}$ & $\begin{array}{c}1 \cdot 3 \times 10^{\wedge} 9 \\
\left(4 \cdot 1 \times 10^{\wedge} 8,3 \cdot 0 \times 10^{\wedge} 9\right) \\
\end{array}$ & $\begin{array}{c}3 \cdot 3 \times 10^{\wedge} 8(- \\
\left.1 \cdot 8 \times 10^{\wedge} 9,1 \cdot 8 \times 10^{\wedge} 9\right) \\
\end{array}$ & $0 \cdot 53$ \\
\hline Any Bacteria Positive $\left(>10^{\wedge} 6\right)(n=22)$ & $5(45 \cdot 5 \%)$ & $3(27 \cdot 3 \%)$ & $0 \cdot 45(0 \cdot 05,3 \cdot 59)$ & $0 \cdot 38$ \\
\hline Moraxella catarrhalis $\left(\geq 10^{\wedge} 6\right.$ genome copies/ml) $(\mathrm{n}=22)$ & $0(0 \cdot 0 \%)$ & $1(9 \cdot 1 \%)$ & & $0 \cdot 31$ \\
\hline $\begin{array}{l}\text { Haemophilus influenzae }\left(\geq 10^{\wedge} 6 \text { genome copies } / \mathrm{ml}\right) \\
(\mathrm{n}=22)\end{array}$ & $3(27 \cdot 3 \%)$ & $0(0 \cdot 0 \%)$ & $0 \cdot 00(0 \cdot 00,1 \cdot 12)$ & $0 \cdot 06$ \\
\hline $\begin{array}{l}\text { Streptococcus pneumonia }\left(\geq 10^{\wedge} 6 \text { genome copies } / \mathrm{ml}\right) \\
(\mathrm{n}=22)\end{array}$ & $3(27 \cdot 3 \%)$ & $2(18 \cdot 2 \%)$ & $0 \cdot 59(0 \cdot 04,6 \cdot 80)$ & 0.61 \\
\hline $\begin{array}{l}\text { Count of Bacteria Positive }\left(\geq 10^{\wedge} 6 \text { genome copies } / \mathrm{ml}\right) \\
(\mathrm{N}=22) \\
0 \text { bacteria specific } \mathrm{qPCR}>10^{\wedge} 6 \text { Copies } / \mathrm{ml} \\
1 \text { bacteria specific } \mathrm{qPCR}>10^{\wedge} 6 \text { Copies } / \mathrm{ml} \\
2 \text { bacteria specific } \mathrm{qPCR}>10^{\wedge} 6 \text { Copies } / \mathrm{ml} \\
\end{array}$ & $\begin{array}{c}6(54 \cdot 5 \%) \\
4(36 \cdot 4 \%) \\
1(9 \cdot 1 \%)\end{array}$ & $\begin{array}{l}8(72 \cdot 7 \%) \\
3(27 \cdot 3 \%) \\
0(0 \cdot 0 \%)\end{array}$ & & $0 \cdot 49$ \\
\hline Any Virus or Bacteria $\left(\geq 10^{\wedge} 6\right.$ genome copies $\left./ \mathrm{ml}\right)(\mathrm{N}=22)$ & $5(45 \cdot 5 \%)$ & $3(27 \cdot 3 \%)$ & $0 \cdot 45(0 \cdot 05,3 \cdot 59)$ & 0.38 \\
\hline \multicolumn{5}{|c|}{$\begin{array}{l}\text { Data are presented as mean (SD), median (IQR) and count (\%). Independent sample T-tests, Mann-Whitney U tests and chi-square tests were used to } \\
\text { compare groups. Virus: PCR for Influenza A, Influenza B, Respiratory Syncytial virus A, Respiratory Syncytial virus B, Rhinovirus, } \\
\text { Metapneumovirus, Adenoviurs, Parainfluenza 1, Parainfluenza 2, Parainfluenza 3, Parainfluenza } 4 \text { and Coronavirus. * These add on therapies have not } \\
\text { been studied in severe asthma populations. }\end{array}$} \\
\hline
\end{tabular}

${ }^{a}$ Data shown as count (\%). Effect size shown as odds ratio with $95 \%$ CI

${ }^{\mathrm{b}}$ Data shown as median (IQR). Effect size shown as median difference with bootstrapped $95 \% \mathrm{CI}$ 
Table E9. Change in characteristics from stable on mepolizumab to exacerbation in the sputum eosinophil low $(<2 \%)$ and sputum eosinophil high $(\geq 2 \%)$ subgroups

\begin{tabular}{|c|c|c|c|c|}
\hline $\begin{array}{l}\Delta \text { Change stable on mepolizumab to } \\
\text { exacerbation }\end{array}$ & $\operatorname{Eos}<2 \%(n=24)$ & $\operatorname{Eos} \geq 2 \%(n=21)$ & $\begin{array}{l}\text { Median difference } \\
(95 \% \mathrm{CI})\end{array}$ & $\mathbf{p}$ \\
\hline $\begin{array}{l}\text { Time between Mepo Initiation and Exacerbation } \\
\text { (Years) }\end{array}$ & $1 \cdot 0(0 \cdot 5,1 \cdot 3)$ & $0 \cdot 7(0 \cdot 5,0 \cdot 8)$ & $-0 \cdot 31(-0 \cdot 7,0 \cdot 1)$ & $0 \cdot 20$ \\
\hline Temperature $(\mathrm{C})$ & $0 \cdot 3(-0 \cdot 7,0 \cdot 9)$ & $-0 \cdot 1(-0 \cdot 4,0 \cdot 2)$ & $-0 \cdot 40(-0 \cdot 9,0 \cdot 6)$ & $0 \cdot 26$ \\
\hline Systolic Blood Pressure $(\mathrm{mmHg})$ & $0 \cdot 0(-9 \cdot 0,18 \cdot 0)$ & $-0 \cdot 5(-9 \cdot 5,10 \cdot 5)$ & $-0 \cdot 5(-18 \cdot 0,12 \cdot 0)$ & 0.68 \\
\hline Heart Rate (BPM) & $7 \cdot 5(-5 \cdot 0,15 \cdot 0)$ & $5 \cdot 0(-2 \cdot 0,12 \cdot 5)$ & $-2 \cdot 50(-9 \cdot 5,10 \cdot 0)$ & $0 \cdot 89$ \\
\hline Respiratory Rate (BPM) & $4 \cdot 0(2 \cdot 0,6 \cdot 0)$ & $2 \cdot 0(1 \cdot 0,6 \cdot 0)$ & $-2 \cdot 0(-3 \cdot 0,2 \cdot 0)$ & $0 \cdot 36$ \\
\hline Sp02 Room Air & $0 \cdot 0(-1 \cdot 0,1 \cdot 0)$ & $0 \cdot 0(-2 \cdot 0,1 \cdot 0)$ & $0 \cdot 0(-2 \cdot 0,1 \cdot 0)$ & 0.59 \\
\hline FENO (ppb) & $0 \cdot 0(-7 \cdot 0,11 \cdot 0)$ & $-0 \cdot 5(-14 \cdot 0,26 \cdot 5)$ & $-0 \cdot 5(-14 \cdot 5,24 \cdot 5)$ & $0 \cdot 95$ \\
\hline $\mathrm{FEV}_{1}(\%$ Predicted $)$ & $-10 \cdot 6(-16 \cdot 2,-4 \cdot 9)$ & $-15 \cdot 1(-22 \cdot 9,-4 \cdot 7)$ & $-4 \cdot 5(-12 \cdot 9,5 \cdot 0)$ & $0 \cdot 31$ \\
\hline $\mathrm{FEV}_{1} / \mathrm{FVC}$ & $-3 \cdot 0(-6 \cdot 0,0 \cdot 0)$ & $-5 \cdot 0(-8 \cdot 5,-1 \cdot 9)$ & $-2 \cdot 0(-5 \cdot 3,-2 \cdot 0)$ & $0 \cdot 11$ \\
\hline ACQ5 Total Score & $0 \cdot 8(0 \cdot 4,2 \cdot 4)$ & $1 \cdot 0(0 \cdot 2,1 \cdot 4)$ & $0 \cdot 2(-1 \cdot 2,0 \cdot 6)$ & 0.47 \\
\hline Total cell count $\times 10^{\wedge} 6 / \mathrm{g}(\mathrm{n}=24)$ & $2 \cdot 5(1 \cdot 5,14 \cdot 4)$ & $-0 \cdot 3(-0 \cdot 9,0 \cdot 9)$ & $-2 \cdot 7(-14 \cdot 5,-1 \cdot 0)$ & $0 \cdot 007$ \\
\hline Sputum Neutrophils $\%$ of cells $(n=24)$ & $28 \cdot 3(14 \cdot 7,45 \cdot 8)$ & $7 \cdot 1(-21 \cdot 8,20 \cdot 5)$ & $-21 \cdot 1(-51 \cdot 1,-3 \cdot 8)$ & $0 \cdot 007$ \\
\hline $\begin{array}{l}\text { Sputum Neutrophils Absolute Cell Count } \\
(\text { cells/g) }(\mathrm{n}=24)\end{array}$ & $2 \cdot 1(1 \cdot 4,10 \cdot 4)$ & $0 \cdot 2(-0 \cdot 7,0 \cdot 7)$ & $-1 \cdot 9(-10 \cdot 2,-1 \cdot 0)$ & 0.014 \\
\hline Sputum Eosinophils $\%$ of cells $(n=24)$ & $-0 \cdot 2(-1 \cdot 5,0 \cdot 3)$ & $3 \cdot 3(-0 \cdot 7,5 \cdot 3)$ & $3 \cdot 5(-2 \cdot 2,6 \cdot 1)$ & $0 \cdot 068$ \\
\hline $\begin{array}{l}\text { Sputum Eosinophils Absolute Cell Count } \\
(\text { cells } / g)(n=24)\end{array}$ & $0 \cdot 0(-0 \cdot 0,0 \cdot 0)$ & $0 \cdot 1(0 \cdot 0,0 \cdot 2)$ & $0 \cdot 07(0 \cdot 03,0 \cdot 2)$ & $0 \cdot 005$ \\
\hline Sputum Lymphocyte $\%$ of cells $(n=24)$ & $0 \cdot 0(-0 \cdot 5,0 \cdot 0)$ & $1 \cdot 3(0 \cdot 0,2 \cdot 8)$ & $1 \cdot 3(0 \cdot 0,2 \cdot 8)$ & $0 \cdot 005$ \\
\hline Sputum Macrophages $\%$ of cells $(n=24)$ & $-24 \cdot 4(-31 \cdot 3,-15 \cdot 0)$ & $-6 \cdot 6(-12 \cdot 6,9 \cdot 8)$ & $17 \cdot 7(6 \cdot 7,38 \cdot 8)$ & 0.006 \\
\hline
\end{tabular}


Table E10: Detection of pathogens on qPCR and associated sputum neutrophil (\%) count, including detection of viruses, bacteria detected at any level on qPCR and bacteria detected above the threshold of $11^{\wedge} 6$ genome copies/ml. A) Clinically stable and established on mepolizumab with paired sputum differential cell count and $\mathrm{qPCR}(\mathrm{n}=60)$. B) First exacerbation with sputum per participant with paired sputum differential cell count and qPCR $(n=33)$. C) All exacerbations with paired sputum differential cell count and qPCR $(n=45)$.

\begin{tabular}{|c|c|c|c|c|}
\hline & $\begin{array}{c}\text { Number } \\
\text { positive }(\%)\end{array}$ & $\begin{array}{c}\text { Positive: Sputum neutrophils } \\
(\%)\end{array}$ & $\begin{array}{l}\text { Negative: Sputum } \\
\text { neutrophils }(\%)\end{array}$ & $\mathbf{p}$ \\
\hline \multicolumn{5}{|l|}{ A) Clinically stable $(\mathrm{n}=60)$} \\
\hline Virus & $7(11 \cdot 6)$ & $49 \cdot 6(43 \cdot 6,62 \cdot 2)$ & $43 \cdot 2(26 \cdot 8,71 \cdot 5)$ & $0 \cdot 41$ \\
\hline Bacteria at any level of detection & $32(53 \cdot 3)$ & $58 \cdot 1(30 \cdot 5,78 \cdot 1)$ & $39 \cdot 1(20 \cdot 3,65 \cdot 0)$ & $0 \cdot 08$ \\
\hline Bacteria detected $>10^{\wedge} 6$ genome copies $/ \mathrm{ml}$ & $22(36 \cdot 7)$ & $59 \cdot 3(29 \cdot 5,92 \cdot 0)$ & $41 \cdot 2(29 \cdot 4,64 \cdot 7)$ & $0 \cdot 13$ \\
\hline $\begin{array}{l}\text { Virus or Bacteria at any level of detection (genome } \\
\text { copies } / \mathrm{ml} \text { ) }\end{array}$ & $35(58 \cdot 3)$ & $55 \cdot 9(30 \cdot 7,75 \cdot 8)$ & $38 \cdot 0(18 \cdot 5,65 \cdot 3)$ & $0 \cdot 11$ \\
\hline Virus or bacteria detected $>10^{\wedge} 6$ copies $/ \mathrm{ml}$ & $27(45 \cdot 0)$ & $57 \cdot 2(30 \cdot 7,83 \cdot 0)$ & $40 \cdot 3(23 \cdot 6,65 \cdot 3)$ & $0 \cdot 15$ \\
\hline \multicolumn{5}{|c|}{ B) First exacerbation with sputum per participant (n=33) } \\
\hline Virus & $12(36 \cdot 3)$ & $87 \cdot 2(60 \cdot 8,92 \cdot 9)$ & $70 \cdot 8(37 \cdot 1,94 \cdot 7)$ & $0 \cdot 56$ \\
\hline Bacteria at any level of detection & $22(66 \cdot 7)$ & $83 \cdot 7(53 \cdot 5,94 \cdot 8)$ & $70 \cdot 8(36 \cdot 5,88 \cdot 5)$ & $0 \cdot 35$ \\
\hline Bacteria detected $>10^{\wedge} 6$ genome copies $/ \mathrm{ml}$ & $13(39 \cdot 4)$ & $94 \cdot 7(62 \cdot 3,97 \cdot 7)$ & $64 \cdot 1(36 \cdot 8,88 \cdot 4)$ & $0 \cdot 025$ \\
\hline $\begin{array}{l}\text { Virus or Bacteria at any level of detection (genome } \\
\text { copies } / \mathrm{ml} \text { ) }\end{array}$ & $27(81 \cdot 8)$ & $86 \cdot 0(53 \cdot 5,94 \cdot 8)$ & $53 \cdot 9(36 \cdot 5,72 \cdot 5)$ & $0 \cdot 19$ \\
\hline Virus or bacteria detected $>10^{\wedge} 6$ copies $/ \mathrm{ml}$ & $20(60 \cdot 6)$ & $89 \cdot 8(65 \cdot 5,95 \cdot 5)$ & $50 \cdot 5(36 \cdot 5,70 \cdot 8)$ & $0 \cdot 002$ \\
\hline \multicolumn{5}{|l|}{ C) All exacerbations with sputum ( $n=45)$} \\
\hline Virus & $16(35 \cdot 6)$ & $87 \cdot 2(56 \cdot 5,94 \cdot 7)$ & $70 \cdot 8(36 \cdot 2,91 \cdot 9)$ & $0 \cdot 39$ \\
\hline Bacteria at any level of detection & $27(60 \cdot 0)$ & $85 \cdot 5(50 \cdot 5,94 \cdot 8)$ & $69 \cdot 8(36 \cdot 2,88 \cdot 5)$ & $0 \cdot 20$ \\
\hline Bacteria detected $>10^{\wedge} 6$ genome copies $/ \mathrm{ml}$ & $15(33 \cdot 3)$ & $87 \cdot 1(59 \cdot 4,97 \cdot 7)$ & $64 \cdot 1(36 \cdot 2,90 \cdot 7)$ & $0 \cdot 07$ \\
\hline $\begin{array}{l}\text { Virus or Bacteria at any level of detection (genome } \\
\text { copies } / \mathrm{ml} \text { ) }\end{array}$ & $33(73 \cdot 3)$ & $85 \cdot 5(50 \cdot 5,94 \cdot 8)$ & $53 \cdot 9(35 \cdot 8,85 \cdot 6)$ & $0 \cdot 18$ \\
\hline Virus or bacteria detected $>10^{\wedge} 6$ copies $/ \mathrm{ml}$ & $26(57 \cdot 8)$ & $88 \cdot 4(59 \cdot 4,95 \cdot 1)$ & $50 \cdot 5(35 \cdot 5,80 \cdot 5)$ & $0 \cdot 011$ \\
\hline
\end{tabular}


Figure E3. Paired sputum when stable and at first exacerbation with sputum per participant $(\mathrm{n}=24)$.

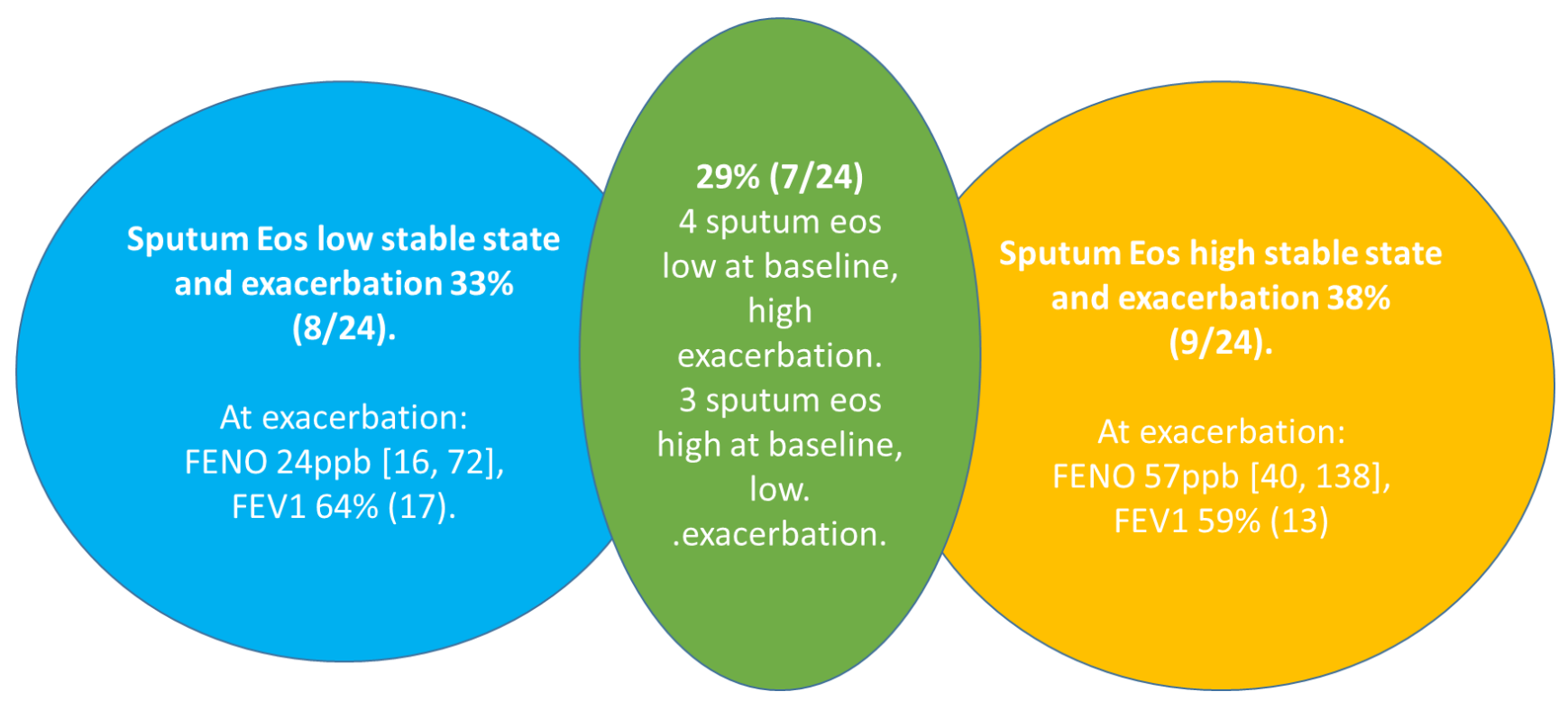

Analysis of paired sputum when stable on mepolizumab and first exacerbation with sputum per exacerbator: Nine of the paired samples (38\%) had elevated sputum eosinophils ( $\geq 2 \%)$ both when stable on mepolizumab and at exacerbation. For these 9 patients, median sputum eosinophils was $14 \%(3.3,36.5)$ when stable on mepolizumab and $20 \cdot 5 \%$ [5.3, 39.0] at exacerbation. At exacerbation, median FENO was $57(40,138), \mathrm{FEV}_{1}$ was 59\% (13).

Eight of the paired samples had a low sputum eosinophil count $(<2 \%)$ when stable on mepolizumab and at exacerbation, with a median sputum eosinophil count of $0 \cdot 12 \%(0 \cdot 0,0 \cdot 8)$ when stable on mepolizumab and $0 \cdot 2 \%$ $(0 \cdot 04,0 \cdot 7)$ at exacerbation. At exacerbation, median FENO was 24 ppb $(16,72), \mathrm{FEV}_{1} 64 \%(17)$. Four patients had a sputum eosinophil count of less than two percent (range $0 \%$ to $1.25 \%$ ) when stable on mepolizumab and two percent or greater (range of $2.9 \%$ to $5.5 \%$ ) at exacerbation. Three patients had an eosinophil count of two percent or greater when stable on mepolizumab (range 2.5 to $3 \%$ ) and less than two percent at exacerbation (range $0.75 \%$ to $1 \%$ ). 


\section{Online supplement references:}

1. NICE 2017. 1 Recommendations | Mepolizumab for treating severe refractory eosinophilic asthma | Guidance | NICE. 2017 [cited 2020 Jan 21]; URL:https://www.nice.org.uk/guidance/TA431/chapter/1-Recommendations Accessed 10 Mar 2020

2. Consortium SS medicines. mepolizumab (Nucala) [Internet]. Scottish medicines consortium. 2016 [cited 2020 Mar 22]. URL: https://www.scottishmedicines.org.uk/medicinesadvice/mepolizumab-nucala-fullsubmission-114916/ Accessed 10 Mar 2020

3. Juniper EF, O’Byrne PM, Guyatt GH, Ferrie PJ, King DR. Development and validation of a questionnaire to measure asthma control. Eur Respir J. 1999;14(4):902-7.

4. Juniper EF, Bousquet J, Abetz L, Bateman ED. Identifying "well-controlled" and "not wellcontrolled" asthma using the Asthma Control Questionnaire. Respir Med. 2006;100(4):616-21.

5. Juniper EF, Guyatt GH, Cox FM, Ferrie PJ, King DR. Development and validation of the Mini Asthma Quality of Life Questionnaire. Eur Respir J. 1999;14(1):32-8.

6. Jones PW. St. George's respiratory questionnaire: MCID. In: COPD: Journal of Chronic Obstructive Pulmonary Disease. 2005;2;75-9. 